INSTITUTO SUPERIOR ANÍSIO TEIXEIRA

Lorena Vidal Leite Alves

ATITUDES FEMINISTAS PRESENTES NA NARRATIVA DE OUTLANDER: A VIAJANTE DO TEMPO DE DIANA GABALDON

São Gonçalo — RJ

2020 
Lorena Vidal Leite Alves

\title{
ATITUDES FEMINISTAS PRESENTES NA NARRATIVA DE OUTLANDER: A VIAJANTE DO TEMPO DE DIANA GABALDON
}

\begin{abstract}
Monografia apresentada ao curso de Graduação em Letras Tradução PortuguêsInglês do Instituto Superior Anísio Teixeira ISAT como requisito parcial à obtenção do título de Bacharel em Letras Tradução Português-Inglês
\end{abstract}

Orientador: Prof. Dr. Bruno Cesar Ferreira Vieira

São Gonçalo - RJ 


\title{
ATITUDES FEMINISTAS PRESENTES NA NARRATIVA DE OUTLANDER: A VIAJANTE DO TEMPO DE DIANA GABALDON
}

\begin{abstract}
Monografia apresentada ao curso de Graduação em Letras Tradução PortuguêsInglês do Instituto Superior Anísio Teixeira ISAT como requisito parcial à obtenção do título de Bacharel em Letras Tradução Português-Inglês

Orientador: Prof. Dr. Bruno Cesar Ferreira Vieira
\end{abstract}

Prof. Dr. Bruno Cesar Ferreira Vieira

São Gonçalo, RJ, 22 de novembro de 2020. 


\section{DEDICATÓRIA}

Dedico este trabalho acadêmico aos meus pais, Eloisa e Ronaldo, por me apoiarem a seguir a carreira que eu queria. Às minhas colegas de faculdade, Luana e Thamires, por passarem mais de quatro anos juntas nessa jornada. Ao meu orientador Bruno, por me guiar neste trabalho final. A todos os meus professores que compartilharam seus conhecimentos comigo. E por último, a todas as mulheres que lutaram bravamente e fizeram a escrita deste trabalho ser possível. 


\section{AGRADECIMENTOS}

Primeiramente, agradeço aos meus pais pela disponibilidade financeira para aquisição de livros e outros materiais para a confecção deste estudo. Ao meu orientador, Prof. Dr. Bruno C. F. Vieira, por fornecer obras que auxiliaram na construção de conhecimentos que permitiram a análise do objeto de estudo aqui proposto. Por fim, agradeço a professora Simone Azevedo Araújo Ribeiro pelo compartilhamento de informações sobre Outlander que tanto facilitaram a jornada durante esse processo de escrita, demonstrando, com isso, a importância das mulheres em dividirem conhecimentos e vivências para o crescimento da colaboração entre mulheres. 
"Oh, you on that feminist tip?

HELL YEAH, I AM!"

(Little Mix - Joan of Arc) 


\section{RESUMO}

Este trabalho de conclusão de curso foi pensado para mostrar que as propostas do movimento feminista também estão presentes em personagens femininas dentro da literatura ficcional Norte Americana. Escolhi como objeto do meu estudo a obra Outlander: a viajante do tempo, de Diana Gabaldon. Dividi esse trabalho em três capítulos, pois assim poderia desenvolver melhor todas as informações que gostaria de transmitir aos leitores. No primeiro capítulo, apresentarei informações sobre a obra literária, a autora Diana Gabaldon e sobre os personagens, que acredito ser de grande relevância para demonstrar que algumas personagens femininas da narrativa apresentam atitudes feministas. No segundo capítulo, apresentarei informações sobre o feminismo, suas três ondas e algumas ramificações do movimento. Já no terceiro capítulo, finalizarei o meu trabalho analisando cenas que possuem opressão patriarcal contra as mulheres e cenas que mostram atitudes feministas. Todo meu discurso é baseado em conceitos, teorias e falas feministas.

Palavras-chave: Outlander. atitudes feministas. feminismo. 


\begin{abstract}
This study was designed to show that the proposals of the feminist movement are also present in female characters in fictional North American literature. I chose Diana Gabaldon's Outlander as the object of my study. I divided this work into three chapters so that I could better develop all the information I would like to convey to the readers. In the first chapter, I will present the necessary information about the literary work, about the author Diana Gabaldon and about the characters, who I believe are of great relevance to demonstrate that some female characters in the narrative have feminist attitudes. In the second chapter, I will present theoretical information about feminism, its three waves and some ramifications of the movement. In the third chapter, I will finish my work analyzing scenes that have patriarchal oppression against women and scenes that show feminist attitudes. All my discourse is based on feminist concepts, theories and speeches.
\end{abstract}

Key words: Outlander. feminist attitudes. feminism. 


\section{SUMÁRIO}

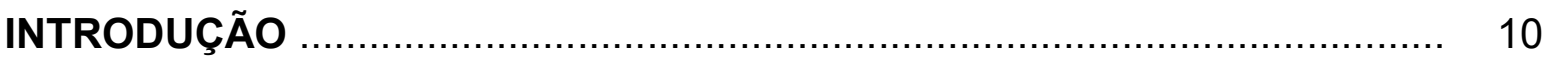

1 Conhecendo Outlander ..................................................................... 15

1.1 Conhecendo a autora Diana Gabaldon ................................................... 21

1.2 Conhecendo os personagens ........................................................ 24

20 Feminismo e suas 3 ondas ............................................................. 33

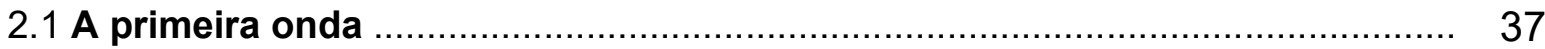

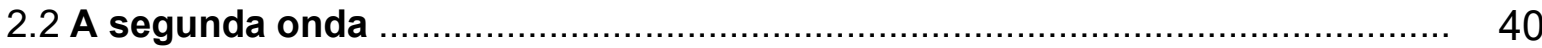

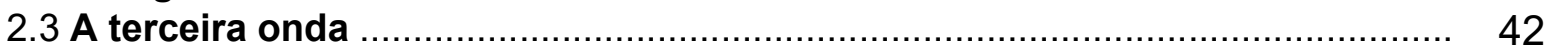

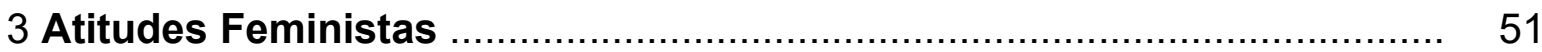

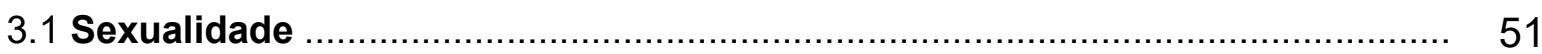

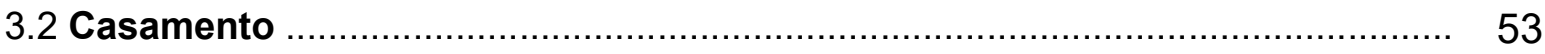

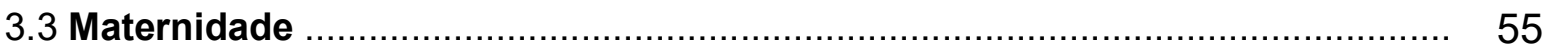

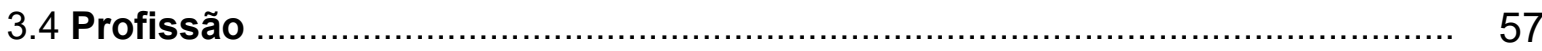

3.5 Violência ............................................................................................ 59

3.6 Patriarcado e/ou comportamento fora do padrão …………………………. 64

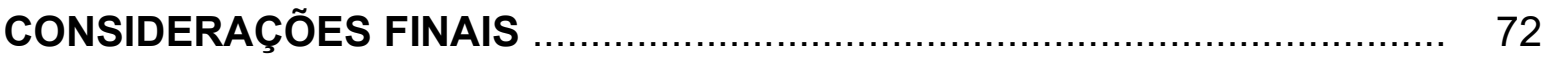

REFERÊNCIAS BIBLIOGRÁFICAS …................................................ 75 


\section{INTRODUÇÃO}

O número de obras literárias que ganham versões televisivas está em ascensão na atualidade. Na verdade, essa transição das narrativas escritas para o meio midiático visual já é intenso no campo cinematográfico desde o século XX. Na primeira década de 2000, testemunhamos diversas obras classificadas como Literatura Infanto-Juvenil ou Literatura de Fantasia ganharem adaptações para as telas dos cinemas. Duas sagas são os exemplos mais concretos que comprovam essa transição e sua aceitação pelo grande público: Harry Potter (J. K. Rowling, 1997) e Jogos Vorazes (Suzanne Collins, 2008).

Com o aumento dos serviços de streaming de vídeos, tais como: Netflix, Amazon Prime e Disney + , diversas obras literárias ganharam adaptações para o formato de seriados. Um grande sucesso da HBO, Game of Thrones (2008) é baseado na coleção As Crônicas de Gelo e Fogo (1996) de autoria do romancista norte-americano George R. R. Martin.

No Brasil, o livro escrito por Javier Peña intitulado Killing Pablo (2001) foi o ponto de partida para a construção do seriado Narcos (2015) que contou a história do narcotraficante colombiano Pablo Escobar (interpretado pelo ator brasileiro Wagner Moura). Uma série que faz muito sucesso entre os adolescentes, Os 13 Porquês, lançado pela Netflix em 2017, é uma adaptação do livro homônimo que foi escrito por Jay Asher em 2007.

Ainda nesse campo, temos igualmente a obra literária Outlander (1991) (Outlander: a viajante do tempo, no Brasil) que se tornou um seriado. Por causa da obra já ser viabilizada em dois formatos (seriado e livro) e ter uma empatia do público (televisivo e leitor) com a personagem Claire e com a obra, escolhi fazer um estudo sobre atividades feministas em uma narrativa com a obra Outlander: a viajante do tempo, pois, além de gostar do enredo por ele mesmo, também acredito que o trabalho alcançará um número maior de pessoas que já estão familiarizadas com Outlander no formato tanto cinematográfico quanto literário.

Este trabalho de conclusão de curso não é pautado na análise ou observações do seriado Outlander, mas sim em sua narrativa escrita. Bem como, quando o público lê as páginas da obra Outlander, muitos demonstram surpresa ao perceberem o modo como as mulheres eram tratadas na época para a qual a personagem Claire foi levada. Esse foi outro grande motivo para escolher a obra como objeto de estudo, pois o trabalho abordará os conceitos de feminismo 
existentes ao longo dos anos, e irá comparar cenas e atitudes de personagens femininas da narrativa com teorias e falas feministas.

Portanto, a justificativa geral para estudar e escrever um trabalho de cunho acadêmico sobre uma obra literária considerada não canônica valida-se pela sua observação e análise pelo viés das teorias do feminismo. Além disso, tais teorias são mais que justificadas quando encontramos nelas as lutas das personagens femininas e sua não aceitação ao que era imposto. Essa recusa em obedecer o estipulado pelo patriarcado demonstra que as personagens apresentam atos ou comportamentos que hoje podem ser interpretados pelas correntes do Feminismo.

A obra foi escrita por Diana Gabaldon e conta a história da inglesa Claire Randall, enfermeira durante a Segunda Guerra Mundial. Ela viaja com seu marido Frank para a Escócia para uma reaproximação após anos separados pela guerra. Entretanto, Claire volta misteriosamente 200 anos no tempo, tendo que enfrentar sozinha a realidade de 1743.

Além de ser removida de sua época e da companhia de seu esposo, a personagem principal está rodeada por uma atmosfera de tensão civil entre a Escócia e a Inglaterra, em um período em que a mulher não possuía voz ou visibilidade. A viagem no tempo, experimentada por Claire não se tratava de apenas de um deslocamento temporal, mas sim de um deslocamento de discurso, ou ausência dele.

A verdade é que nada se movia, nada mudava, nada parecia acontecer e, ainda assim, eu experimentava uma sensação de terror tão grande que perdi completamente a noção de quem ou o quê eu era, de onde me encontrava. Estava no âmago do caos e nenhuma força física ou mental era útil contra isso. (GABALDON, 2018, p. 43)

A metodologia de pesquisa deste projeto é a pesquisa bibliográfica, e sua finalidade é alcançar o objetivo geral do trabalho. Este tipo de pesquisa é um dos mais comuns e adequados ao que se deseja realizar neste estudo, sendo ela parte integrante em todos os trabalhos científicos. Esse método é realizado a partir de uma coleta de dados, no caso deste trabalho, os dados serão baseados na obra literária Outlander e em outros livros que tenham relação direta ou indireta com a obra; em livros e artigos sobre teorias feministas e a posição da mulher no século $\mathrm{XXI}$; sobre a história do feminismo; e outras fontes. Todas essas referências serão usadas como objeto de estudo, assim como fonte para utilização de citações. 
Segundo Lima e Mioto (2007, p. 2), “a pesquisa bibliográfica implica em um conjunto ordenado de procedimentos de busca por soluções, atento ao objeto de estudo, e que, por isso, não pode ser aleatório." Portanto, esse é um dos métodos de pesquisa que serve como embasamento para todos os assuntos pesquisados, analisando variáveis que um problema pode ter, percebendo divergências entre temas, explicitando o que está nas entrelinhas, comparando opiniões e afirmações de diferentes autores sobre o mesmo assunto em estudo, entre outros.

Com o intuito de localizar os leitores e atingir o objetivo geral deste trabalho, o primeiro capítulo apresentará ao leitor, que porventura desconheça sobre a obra literária em questão, dados sobre a narrativa, seus spin-offs, sua versão televisiva de grande sucesso transmitida pelo canal Starz ${ }^{1}$ e o serviço de streaming Netflix. Em adição a essas informações, este capítulo discorrerá sobre informações pessoais e a bibliografia literária a respeito da autora de Outlander: a viajante do tempo, Diana Gabaldon.

Ressalto que acredito ser de grande interesse para o público leitor que este capítulo também incluirá informações sobre os personagens de certa relevância para a narrativa, envolvendo principalmente, as personagens femininas (Claire Randall Fraser, Geillis Duncan, Jenny Fraser Murray, entre outras) que serão citadas nos capítulos posteriores para explicitar que certas atitudes, comportamentos e pensamentos nas ações delas possam ser consideradas feministas.

O segundo capítulo conceituará o que é feminismo e informará de maneira sucinta sobre as teorias feministas presentes ao longo dos anos. Além disso, entendendo a afirmativa de Jenainati (2007, p. 3 - tradução nossa) de que "Feminismo é a luta para acabar com a opressão sexista.2", este capítulo abordará o porquê de as mulheres precisarem ainda da voz e representatividade que o movimento feminista as dá. Primeiro, explicarei o que é feminismo para que, de forma introdutória, seja definido o viés pelo qual a análise do trabalho segue e serão desmistificados conceitos errôneos que são atribuídos ao movimento. E por último, irei discorrer sobre as três ondas do feminismo.

Embora diversas conquistas feministas estejam concretizadas na atualidade, estamos muito longe do que o ideal do movimento feminista almeja para os padrões de comportamentos e equalidade de direitos de uma sociedade contemporânea. É

\footnotetext{
${ }^{1}$ Disponível em: <https://www.starz.com/us/en/>. Acesso em: 30 set. 2020.

2 "Feminism is the struggle to end sexist oppression." (JENAINATI, 2007, p. 3)
} 
de grande relevância também ressaltar que ainda existem questões pertinentes de importância na sociedade mundial, oriundas do século XXI, que ainda carecem de respostas e pesquisas para que tenhamos um melhor entendimento do que vivemos no presente.

Com base na citação de Elaine Showalter (1993, p. 62): "Com suas novas oportunidades de instrução, trabalho e mobilidade, a nova mulher percebia ter alternativas ao casamento". O terceiro capítulo identificará e analisará as passagens retiradas da obra de Gabaldon que apresentem atitudes e pensamentos das personagens femininas da narrativa que poderiam ser lidas com uma perspectiva feminista e/ou que representem comportamentos contrários ao padrão patriarcal imposto às mulheres nos anos de 1743 e 1945.

Dado que a necessidade da existência do movimento feminista ainda é questionada, entender por que tanto a personagem principal como outras personagens tomam determinadas atitudes ao longo da narrativa pode apontar para a sociedade atual, em que ainda se faz necessária maior representatividade do discurso feminista. Desta forma, este capítulo trará aos olhos dos leitores exemplos concretos da importância da luta por direitos iguais e fim do patriarcado.

A fundamentação será fornecida pelas teorias e falas de mulheres, estudiosas e críticas do movimento feminista como Elaine Showalter (1941), Márcia Arán (? 2011), Simone Beauvoir (1908 - 1986), Virginia Woolf (1882 - 1941), Djamila Ribeiro (1980), bell hooks (1952), Branca Moreira Alves (1940), Jaqueline Pitanguy (1945), Mary Wollstonecraft (1759 - 1797), entre outras. Ainda no terceiro capítulo, antes de chegar às considerações finais, ele será dividido em subcapítulos, cada um contendo uma temática que o movimento feminista busca conscientizar e atingir a equalidade. Como exemplo: violência doméstica, profissão, casamento, entre outros.

Por isso, este trabalho é voltado primeiramente para as mulheres, que, acreditando no movimento feminista, ainda precisam de mais representatividade e voz em seus discursos; e a todas as pessoas que não acreditam na necessidade do movimento feminista, pois ainda não são capazes de observarem o quanto nossa sociedade é permeada pelo discurso patriarcal opressor. Seguidamente, este trabalho destina-se também para estudantes e professores do curso de Letras sobretudo das áreas de Sociologia e Literaturas de Língua Inglesa; que com este breve estudo possam exemplificar e correlacionar as narrativas presentes em obras literárias com as questões sociais vigentes. 


\section{Conhecendo Outlander}

Embora a narrativa de Outlander: a viajante do tempo seja conhecida pelo público através do seriado de TV, faz-se necessário informar fatores que tornam essa narrativa um sucesso, e, principalmente, situar o leitor no que diz respeito a obra literária de Diana Gabaldon, uma vez que este estudo não diz respeito a produção televisiva, mas sim a obra literária.

Para tanto, este capítulo apresentará de início um breve relato sobre a obra literária em estudo e suas vertentes. A seguir, baseando-se nas redes sociais da autora e na coletânea de entrevistas reunidas, será discorrido uma pequena biografia sobre Diana Gabaldon. Por fim, com o intuito de contribuir para um melhor entendimento do trabalho, é apresentado um breve resumo sobre os personagens da obra que aparecerão neste estudo.

A série de livros Outlander contém onze ficções históricas e fantásticas traduzidas até o momento, sendo que na versão original em inglês há apenas oito ao todo. As narrativas em ordem de lançamento ${ }^{3}$ são: Outlander: a viajante do tempo (original 1991, tradução 2016); Outlander: a libélula no âmbar (original 1992, tradução 2016); Outlander: o resgate no mar, parte I (original 1993, tradução 2017); Outlander: o resgate no mar, parte II (original 1993, tradução 2017); Outlander: os tambores de outono, parte I (original 1996, tradução 2016); Outlander: os tambores de outono, parte II (original 1996, tradução 2016); Outlander: a cruz de fogo, parte I (original 2001, tradução 2017); Outlander: a cruz de fogo, parte II (original 2001, tradução 2017); Outlander: um sopro de neve e cinzas (original 2005, tradução 2018); Outlander: ecos do futuro (original 2009, tradução 2019); e Written in my Own Heart's Blood (original 2014) que ainda não possui tradução no Brasil.

A autora, Diana Gabaldon, declarou em sua conta oficial na rede social Twitter $^{4}$ em dezembro de 2018 que o nono livro da série seria lançado em 2019 com o título Go Tell the Bees that I Am Gone, e também declarou que o décimo livro seria lançado logo a seguir. Entretanto, nenhum dos dois livros foram lançados no ano prometido e nem até o ano de 2020 enquanto escrevo esse trabalho de conclusão de curso (TCC).

\footnotetext{
${ }^{3}$ Apresento nesta sequência as respectivas datas de lançamento do original e da tradução no Brasil que acompanham os títulos já traduzidos.

${ }^{4}$ Conta oficial da autora Diana Gabaldon na rede social Twitter (@Writer_DG)
} 
A sinopse do primeiro livro diz que a enfermeira Claire Randall em 1945 aproveita uma segunda lua de mel com o marido em Inverness, na Escócia, já que a Segunda Guerra Mundial tinha finalmente acabado. Ocorre que Claire, sem querer, ao visitar um círculo de pedras onde rituais pagãos acontecem, é teletransportada para a Inverness de 1743 no meio de clãs guerreiros e uma rebelião jacobita.

A enfermeira presa no passado enfrenta ameaças, perigos e uma paixão por Jamie Fraser que é um Lorde guerreiro escocês exilado do seu clã. Claire se arrisca em uma época desconhecida e encara a batalha interna entre seus sentimentos pelo seu marido de 1945 (Frank) e pelo jovem Jamie, seu segundo marido (1743); tudo isso com a incerteza se voltará ou não para 1945.

No site oficial ${ }^{5}$ da autora Diana Gabaldon existe um setor onde há perguntas frequentes respondidas pela própria autora, e nesse espaço ela comenta que o conceito de viagem no tempo e toda essa barreira de gênero em Outlander foi culpa da própria personagem Claire, já que quando estava escrevendo uma das cenas da ficção, a autora visualizou em sua mente a personagem respondendo de forma moderna a um homem que a questionava sobre quem ela era.

Então, a autora preferiu mudar a narrativa de uma ficção diretamente histórica para uma fantástica viagem no tempo, e assim adequar a narrativa à maneira independente e não tão submissa da personagem principal em relação à figura masculina. Em entrevista à $\mathrm{BBC}^{6}$, Gabaldon diz: "Ela (Claire) falava com a autonomia de uma mulher moderna e, depois de pensar sobre o que fazer com ela por algumas páginas, tive a ideia de fazer com que ela viajasse no tempo." (GABALDON, 2018, tradução nossa).

Segundo a obra O futuro do espaço-tempo ${ }^{7}$ (HAWKING, 2005), viagem no tempo é uma hipótese do campo científico da Física que tem a concepção de viajar para diversos momentos do espaço-tempo tanto para o passado ou futuro quanto para outras realidades paralelas. Atualmente, a maioria dos teóricos físicos acreditam que possibilidade prática de uma viagem no tempo acontecer é quase inexistente devido a fatores de que ainda não há uma tecnologia que possibilite a viagem, então, o deslocamento pelo espaço-tempo, por enquanto, é somente teoria.

\footnotetext{
${ }^{5}$ Disponível em: <http://www.dianagabaldon.com/>. Acesso em: 31 ago. 2020.

6 "She was speaking in a modern tone of voice and, after wrestling with her for a few pages, I hit upon the idea of having her travel back in time." (GABALDON, 2018, entrevista à BBC) Disponível em: <https://www.bbc.com/news/uk-scotland-37467296>. Acesso em: 26 ago. 2020.

${ }^{7}$ HAWKING, Stephen W. et al. O futuro do espaço-tempo. 8. ed. Tradução: José Viegas Filho. São Paulo: Companhia das Letras, 2005.
} 
Em entrevista ao site britânico The Press and Journal, ${ }^{8}$ a autora Diana Gabaldon diz que o primeiro volume da série Outlander foi trocado de Cross Stitch (título dado à primeira edição no Reino Unido) para Outlander porque o título soava muito como um livro de bordado, então o nome foi alterado na edição estadunidense. Gabaldon pensou nesse título porque significaria a profissão de enfermeira/curandeira que a personagem Claire tem tanto no presente dela como no passado. Também significaria a letra xis $(X)$ porque seria as viagens que Claire faria, um para o passado e a outra de volta ao presente dela.

Quando foi entrevistada pelo site britânico The Scotsman ${ }^{9}$ e pela $B B C^{10}$, Gabaldon disse que escolheu a Escócia para o cenário de Outlander porque ela assistiu a um episódio da série de televisão Doctor Who ${ }^{11}$ em que o personagem Jamie McCrimmon estava. A autora ficou encantada pelo personagem de kilt que veio de 1745, então, ela começou a procurar sobre o ano específico, o país de origem do personagem e logo descobriu sobre a rebelião jacobita ${ }^{12}$. Ela gostou tanto destes fatos que pôs em sua obra e homenageou o personagem masculino principal com o nome Jamie.

O jornal on-line Express ${ }^{13}$, em um artigo sobre a série Outlander, afirma que Craigh na Dun, o famoso círculo de pedras que transporta Claire para o passado, não existe, foi completamente inventado e gravado em estúdio. Entretanto, outros

\footnotetext{
${ }^{8}$ Disponível em: <https://www.pressandjournal.co.uk/fp/news/scotland/2039021/the-big-interviewdiana-gabaldon-on-boiling-frogs-the-outlander-effect-and-being-pulled-over-by-the-dundee-police/> . Acesso em: 26 ago. 2020.

${ }^{9}$ Disponível em: <https://www.scotsman.com/news/interview-diana-gabaldon-2442942>. Acesso em: 26 ago. 2020.

${ }^{10}$ Disponível em: <https://www.bbc.com/news/av/uk-scotland-28834278>. Acesso em: 26 ago. 2020.

${ }^{11}$ Dr. Who é considerada a série televisiva de ficção científica mais longa da história. Ela começou a ser transmitida em 1963, tem 26 temporadas e mais de 500 episódios. Ela fala sobre um Doutor alienígena e seus amigos que com sua máquina do tempo ajudam a combater inimigos, salvar pessoas e corrigir alguns erros feito pela humanidade.

${ }^{12}$ A rebelião jacobita deu-se início quando a rainha Anne Stuart morreu e o reinado da casa Hanover começou. James II, filho da rainha Anne, era o próximo na linha de sucessão ao trono, entretanto, ele foi exilado do Reino Unido e se residiu na França. Então, como uma manobra política para retirar os escoceses do trono, os ingleses coroaram George Hanover. George era um nobre alemão, primo da rainha Anne e que não sabia falar inglês. Consequentemente, toda essa situação causou revolta entre o povo escocês que queriam o verdadeiro herdeiro ao trono, James II, como o novo rei. Portanto, os rebeldes acabaram se nomeando jacobitas em referência ao nome latim de James II, Jacobus. Em 1745, a rebelião jacobita apoiou o Príncipe Charlie, filho de James II e neto da rainha Anne, a recolocar a família Stuart de volta ao trono. O plano era retirar a coroa da família Hanover a força, então, por isso, os escoceses foram a guerra. Todavia, os jacobitas falharam e perderam a batalha de Culloden que como resultado não colocaram os Stuarts no poder de novo.

PRIESTLEY, J. B.; SPEAR, Josephine. Adventures in English Literature. Vol. 1. USA: Harcourt Brace Jovanovich, 1963.

${ }^{13}$ Disponível em: <https://www.express.co.uk/showbiz/tv-radio/1238742/Outlander-Craigh-na-Dunreal-location-where-Scotland-Inverness-stones-Clava-Cairns>. Acesso em: 26 ago. 2020.
} 
lugares como Inverness são reais e podem ser visitados. Também há círculos de pedra verdadeiros e muito famosos no Reino Unido como, por exemplo, Stonehenge, em Wiltshire.

O turismo, principalmente na Escócia, aumentou com a visibilidade da série de livros e da série televisiva. Tanto que o site Visit Scotland ${ }^{14}$, tem uma seção só para informações sobre lugares turísticos baseados em todo o produto Outlander. Nele, podem ser encontrados lugares de filmagens e lugares históricos como, por exemplo, castelos, lagos, vilas, parques, igrejas, entre outros.

O primeiro livro da série, Outlander: a viajante do tempo, está em primeira pessoa, pois a autora achou mais confortável escrevê-lo do ponto de vista da personagem principal feminina, Claire Randall Fraser. Nos outros oito volumes, outros pontos de vista em terceira pessoa são adicionados ao enredo como o de James Fraser, Brianna Randall, entre outros.

Em consequência ao gradual sucesso que Outlander obteve ao longo dos anos, foram gerados alguns spin-offs da série de livros físicos. Também podendo ser chamado de derivagem, a palavra spin-off tem significado de produto derivado e/ou complementar de um trabalho anterior, ramificação, continuação, e produto originário de outro.

Por isso, além dos livros físicos também foram criados: as versões em e-book e audiobook, uma graphic novel, um livro de colorir, dois guias sobre Outlander, e um musical. Há também quatro contos, sete novelas, e uma série televisiva. A versão e-book dos livros físicos está completa, contendo todos os oito volumes em inglês e os onze volumes em português brasileiro (Pt-br). A versão audiobook dos livros físicos está completa, contendo todos os oito volumes em inglês lidos por Davina Porter; entretanto, há os onze volumes em português brasileiro, porém, não é uma versão oficial e sim, feita por fãs.

A versão graphic novel só contém um volume intitulado The Exile: An Outlander Graphic Novel (2010) e não tem em Pt-br. O livro de colorir tem desenhos que remetem ao primeiro volume da série e também não tem versão em português. Os dois guias sobre a série são chamados The Outlandish Companion (1999 e 2015) e neles há sinopses e informações sobre o universo das narrativas. O musical sobre a série não estreou até o momento, porém, suas músicas já foram gravadas e

\footnotetext{
${ }^{14}$ Disponível em: <https://www.visitscotland.com/see-do/attractions/tv-film/outlander/>. Acesso em: 26 ago. 2020 .
} 
estão compilados em um CD à venda na Amazon ${ }^{15}$. Ele é chamado Outlander: The Musical.

Os quatro contos estão reunidos em um único volume intitulado $A$ Trail of Fire (2012), onde personagens que apareceram na série de livros Outlander têm narrativas paralelas contadas ali. Os contos são: The Custom of the Army, A Plague of Zombies, A Leaf on the Wind of All Hallows, e The Space Between. Os dois primeiros têm Lorde John como seu personagem principal, o terceiro tem os pais do personagem Robert MacKenzie como principais, e o último tem Michael Murray e Joan MacKimmie como personagens principais. Este volume com quatro contos não tem versão traduzida para o português brasileiro.

Os sete romances também estão reunidos em um único volume. Ele é intitulado Seven Stones of Stand or Fall (2017), nele há narrativas paralelas contadas por personagens que aparecerem na série de livros Outlander. As novelas são: The Custom of the Army, A Plague of Zombies, A Leaf on the Wind of All Hallows, The Space Between, Virgins, A Fugitive Green, e Besieged. Os quatro primeiros citados no parágrafo anterior foram relançados neste volume também; além deles, outros três contos foram adicionados.

O primeiro (Virgins) tem personagem masculino Jamie Fraser e o personagem lan Murray, amigo de infância de Jamie e futuramente seu cunhado, como os principais; o segundo (A Fugitive Green) tem Minnie Rennie, uma aprendiz de negociante de livros raros de dezessete anos e futuramente cunhada de Lorde John Grey, como principal; e o terceiro (Besieged) tem Lorde John, um nobre aventureiro e oficial do exército de Sua Majestade, como principal.

A série televisiva baseada nos livros tem atualmente cinco temporadas completas. Ela estreou em 2014 nos Estados Unidos pelo canal de TV Starz, tendo a Sony Pictures Television como detentora dos direitos da série. Possui um contrato até a sexta temporada, por enquanto, e desfruta de Robert D. Moore como o desenvolvedor da série e a própria Diana Gabaldon como consultora. Além de ser a autora dos livros que baseiam a série, Gabaldon é também consultora da produção televisiva; além disso, ela também teve a oportunidade de escrever alguns poucos episódios da série.

\footnotetext{
${ }^{15}$ Disponível em: <https://www.amazon.com/Outlander-Musical-Kevin-Walsh/dp/B00434DA56>. Acesso em: 26 ago. 2020.
} 
As temporadas têm em média de doze a dezesseis episódios. Quem faz a personagem feminina principal é a atriz irlandesa Caitriona Balfe, e quem faz o personagem masculino principal é o ator escocês Sam Heughan. No Brasil, a série televisiva é transmitida na plataforma FOX Premium APP \& TV 16 onde estão disponíveis as cinco temporadas lançadas oficialmente e na Netflix, onde está disponível até a quarta temporada em seu catálogo. Em ambas as plataformas com a classificação etária de dezesseis anos.

A música tema da série televisiva foi composta pelo músico americano Bear McCreary. Ela é uma adaptação do poema Sing me a Song of a Lad that is Gone (1896), escrito pelo poeta e escritor escocês Robert Louis Stevenson ${ }^{17}$ com a melodia de The Skye Boat Song, uma canção folclórica escocesa que retrata a fuga do príncipe Charles Edward Stuart após sua derrota na Batalha de Culloden em 1746.

$\mathrm{Na}$ segunda, terceira e quarta temporada ocorrem pequenas mudanças para adaptar aos acontecimentos ocorridos no contexto da história decorrida naquela temporada. Sendo elas: uma parte da música de abertura cantada em francês na segunda temporada; uma parte da música de abertura com sonoridade caribenha na terceira temporada e uma parte da música de abertura com sonoridade da época da América do Norte colonial na quarta temporada.

A primeira temporada de Outlander teve uma pontuação de 73/100 no Metacritic $^{18}$, um site de críticas e resenhas respeitado pelos especialistas e muito influente no quesito de previsão de vendas; e 7.95/10 no Rotten Tomatoes ${ }^{19}$, outro site de resenhas e críticas muito conceituado por especialistas, mas somente voltado para filmes e televisão.

As cinco temporadas já acumularam mais de sessenta nomeações em premiações pelo mundo, e têm mais de 25 prêmios ganhos. Isso atrai mais pessoas a se interessarem a lerem as obras literárias e torna toda a ficção um grandioso sucesso publicado em mais de vinte países e traduzido para mais de vinte idiomas, entre eles o espanhol, alemão, francês, entre outros.

\footnotetext{
${ }^{16}$ Disponível em: <https://about.foxplay.com/apps/pt/index.php>. Acesso em: 1 out. 2020.

${ }^{17}$ Famoso pela narrativa gótica em português brasileiro chamado de $\mathrm{O}$ estranho caso de Dr. Jekyll e Sr. Hyde ou O médico e o monstro (1886).

${ }^{18}$ Disponível em: <https://www.metacritic.com/>. Acesso em: 26 ago. 2020.

${ }^{19}$ Disponível em: <https://www.rottentomatoes.com/>. Acesso em: 26 ago. 2020.
} 


\subsection{Conhecendo a autora Diana Gabaldon}

Em sua biografia no seu site oficial, Diana Gabaldon, a escritora da série de livros Outlander diz que mora com o marido em Scottsdale, no Arizona, Estados Unidos; que nasceu em 11 de janeiro de 1952; tem ascendência inglesa e mexicanaamericana; ela é mãe de três filhos adultos e também tem netos. Gabaldon declarou que adquiriu um sotaque escocês de tanto ler romances escoceses, e ouvir músicas escocesas e cantores escoceses falando. Gabaldon é considerada uma autora de best-sellers pelo New York Times ${ }^{20}$, e tem um prêmio RITA Award pelo livro Outlander: a viajante do tempo e um Quill Award pelo livro Outlander: um sopro de neve e cinzas.

Em uma entrevista para o jornal Alamogordo Daily News ${ }^{21}$, Gabaldon expôs que tem bacharel em Zoologia pela Universidade do Norte do Arizona; mestrado em Biologia Marinha pela Universidade da Califórnia; doutorado em Ecologia Comportamental pela Universidade do Norte do Arizona; e que lecionou na Universidade Estadual do Arizona por 12 anos. Além da carreira acadêmica, ela também foi a editora fundadora da revista Science Software Quarterly e escreveu quadrinhos para a Disney.

Gabaldon utiliza da metaficção historiográfica como base para toda obra literária da série de livros Outlander. Entende-se metaficção historiográfica por uma existência do passado histórico vinculado a uma narrativa ficcional, podendo ela ser complementar ou alterada para ajustar-se à narrativa. Entre outras palavras, de acordo com Hutcheon "[...] a metaficção historiográfica procura desmarginalizar o literário por meio do confronto com o histórico, e o faz tanto em termos temáticos como formais". (1988, p.145).

Consequentemente, a autora procurou informações verídicas para agregar mais realidade aos seus livros. Gabaldon fez pesquisas simultaneamente enquanto escrevia as narrativas, assim as informações estavam sempre complementando as cenas. A autora comprou livros sobre ervas, medicina, plantas, herbologia, animais, cultura escocesa, geografia, roupas, armas, artilharia, facas, batalhas, guerras, carpintaria, culinária, costura, construção de casas, história de estados e cidades,

\footnotetext{
${ }^{20}$ Disponível em: <https://www.nytimes.com/books/best-sellers/>. Acesso em: 30 ago. 2020.

${ }^{21}$ Disponível em:

<https://web.archive.org/web/20131112073342/http://www.alamogordonews.com/news/ci_13204389>.

Acesso em: 30 ago. 2020.
} 
Revolução Americana, e escravidão; dicionários de idiomas diversos, de gírias, de palavrões; e mapas.

Ao ser entrevistada para a $B B C^{22}$ (2014), Gabaldon conta que não utiliza esboços para escrever suas obras; ela escreve pedaços da narrativa, partes de cenas que está na cabeça dela, e só depois ela as monta em uma ordem cronológica que faça sentido e que possa ser compatível a um contexto histórico. Entretanto, ao escrever, muitas vezes a autora tem que parar o que está escrevendo porque teve inspiração de outra cena, então ela se dirige para essa nova cena e começa a escrevê-la.

Devido a seu fluxo de pensamento e também por causa dos acontecimentos dentro da narrativa, as inspirações que a autora tem não são automáticas ou cronológicas; os fragmentos da narrativa começam a se encaixar a partir de várias cenas já escritas. Portanto, ela normalmente não tem capítulos prontos até estar perto do prazo de entrega do livro à editora, e também só os titula após terminar tudo e tiver uma noção geral do que já está pronto.

No seu site oficial, a escritora complementa as informações dadas na entrevista à $B B C$, de que descarta as cenas ou procura reescrevê-las em outros fragmentos ou nos outros livros da série quando ela percebe fragmentos que não se encaixam no contexto em que está escrevendo. Gabaldon também corta fragmentos que não estão satisfatórios à qualidade que quer transmitir aos seus leitores ou os reescreve até que estejam suficientemente bons.

Para a autora, escrever a série Outlander foi prazeroso, contudo, há cenas na narrativa de Outlander que foram emocionalmente desgastantes para criar e escrever. Algumas delas são: A cena de estupro no primeiro livro, a carta de despedida da personagem Claire para sua filha Bree, e a cena de despedida dos personagens principais Claire e Jamie no segundo livro.

Todavia, há outras cenas na narrativa que, a meu ver, são altamente importantes para retratar o assunto principal deste trabalho que é sobre o feminismo, e que são emocionalmente desgastantes e conflitantes para serem lidas. Algumas das cenas do primeiro livro são: a) Claire sofrendo violência física do marido Jamie; b) Claire sofrendo tentativas de estupro no decorrer da narrativa; c) Claire cedendo a

\footnotetext{
${ }^{22}$ Disponível em: <https://www.bbc.com/news/av/uk-scotland-28834278>. Acesso em: 31 ago. 2020.
} 
se casar com Jamie em 1743 para se proteger; e d) Claire em Craigh na Dun pronta para voltar ao ano de 1945, porém decidindo ficar.

Em uma entrevista em 2015 para a $B B C^{23}$, Gabaldon foi perguntada sobre já ter buscado inspiração em seus leitores. Ela responde que é muito raro, quando aconteceu, nunca foi diretamente. Ela disse que alguns personagens e ideias vieram de conversas com amigos e conhecidos próximos conversando sobre banalidades ou sobre suas obras.

A autora exemplifica essa situação ao citar um personagem. Ela diz que em seu quarto livro haveria um personagem chamado John L. Myers, um revenue agent (agente da receita ou fiscal da Receita Federal) da Carolina do Norte, e quando um cavalheiro leu sobre o personagem, ele pediu para ela colocar o nome do meio de Quincy, pois seu bisavô era chamado John Quincy Myers e tinha a mesma descrição do personagem escrito na narrativa.

No site oficial da autora há outros exemplos de inspirações para suas obras: uma de suas amigas que era fascinada com o misticismo a inspirou a escrever a sacerdotisa Margaret Campbell, que revela uma profecia no terceiro livro da série. Outro exemplo é o personagem do terceiro livro, chamado Padre Fogden, e seu rebanho, que foram inspirados em um amigo da autora que tinha um avô pastor de ovelhas, e que ela e outros amigos sempre brincavam com ele sobre sua relação esses animais.

Ainda convém lembrar que Gabaldon escreveu outras obras de sucesso. Sendo um e-book, antologias com outros autores, e a série de livros spin-off com o personagem de Outlander Lorde John Grey como principal. O e-book é intitulado I Give You My Body (How I Write Sex Scenes) (2016), no qual a autora escreve sobre como ela elabora as cenas de sexo em suas obras.

Algumas antologias em que Gabaldon participou são: o conto Surgeon's Steel na antologia Excalibur (1995); o conto Dream a Little Dream for Me na antologia Mothers \& Daughters: Celebrating the Gift of Love (1998); o conto A Silence at the Heart na antologia Fathers \& Daughters: A Celebration in Memoirs, Stories and Photographs (1999); o conto Mirror Image na antologia Mothers \& Sons: $A$ Celebration in Memoirs, Stories and Photographs (2000); o conto The Castellan na antologia Out of Avalon: An Anthology Of Old Magic And New Myths (2001); o conto

\footnotetext{
${ }^{23}$ Disponível em: <https://www.bbc.com/news/av/uk-scotland-34909433>. Acesso em: 31 ago. 2020.
} 
Dirty Scottsdale na antologia Phoenix Noir (2009); o conto Fogmeister na antologia Highway Kind: Tales Of Fast Cars, Desperate Drivers, and Dark Roads (2016); e o conto Past Prologue na antologia Matchup (2018).

A série de livros spin-off do personagem Lorde John Grey começou com um convite à Diana Gabaldon para escrever um conto para uma antologia britânica sobre crimes históricos, e como Gabaldon não queria utilizar um dos personagens principais de Outlander e nem escrever nada que poderia interferir na série principal, ela escolheu Lorde John.

Ele foi escolhido por ser um personagem importante, fascinante, cheio de aventuras e com muita história ainda não explorada. Ele em adição, tem muitos conflitos pela sua orientação sexual ${ }^{24}$ (homossexual), seu cargo como oficial no exército britânico e sua família, que vem da nobreza. O conto foi intitulado de Lord John and the Hell-Fire Club. Os livros da série Lorde John são: Lord John and the Private Matter (2003); Lord John and the Hand of Devils (2007); Lord John and the Brotherhood of the Blade (2007); and The Scottish Prisoner (2011).

Diante da ampla aceitação dos leitores, sua editora e a própria autora, Gabaldon pensou em escrever mais algumas narrativas sobre as aventuras do Lorde John Grey, o que resultou em um grande sucesso que fez esta série de livros ser complementar à série Outlander. Nenhuma dessas antologias, contos, e-book e livros de Diana Gabaldon citados anteriormente foram publicados aqui no Brasil.

\subsection{Conhecendo os personagens}

Ao contar toda a produção literária que soma oito livros da série Outlander, há mais de cento e cinquenta personagens ao longo da história. Entretanto, este subcapítulo apresentará somente os personagens introduzidos na primeira ficção da série, o livro Outlander. a viajante do tempo, pois este é o volume mais significativo e necessário para o trabalho em questão.

Todavia, nem todos os personagens mencionados no livro serão descritos a seguir porque o compilado será feito apenas dos personagens com interações nas

\footnotetext{
${ }^{24}$ Por orientação sexual entende-se capacidade de cada pessoa de ter uma profunda atração emocional, afetiva ou sexual por indivíduos de gênero diferente, do mesmo gênero ou de mais de um gênero, assim como ter relações íntimas e sexuais com essas pessoas (apud PRINCÍPIOS, 2006).

REIS, T., org. Manual de Comunicação LGBTI+. $2^{a}$ edição. Curitiba: Aliança Nacional LGBTI / GayLatino, 2018.
} 
cenas julgadas relevantes que agregam informações para este trabalho e principalmente o próximo capítulo. Contudo, ao final deste subcapítulo o leitor encontrará uma árvore genealógica para uma melhor referência e entendimento de qual ligação os personagens aqui descritos têm.

Uma curiosidade sobre a autora Diana Gabaldon é que ela não utiliza de gráficos, listas ou fichas sobre seus personagens para desenvolvê-los. Ela escreve tudo sobre seus personagens nos rascunhos do livro mesmo. Normalmente as características dos personagens são escritas por cenas, e enquanto as cenas vão virando capítulos o personagem é construído. Ela diz que não esquece dos personagens porque eles estão em sua mente e ela pode visualizá-los.

Os personagens citados neste subcapítulo serão: Claire Randall Fraser (Claire Beauchamp como nome de solteira); James Fraser (Comumente chamado de Jamie na obra); Frank Randall; Jonathan Randall (Comumente chamado de Black Jack na obra); Reverendo Reginald Wakefield; Geillis Duncan; Dougal MacKenzie; Colum MacKenzie; Edward (Comumente chamado de Ned na obra) Gowan; Padre Bain; Murtagh Fraser; Glenna Fitzgibbons (Comumente chamado de Sra. Fitz na obra); Laoghaire MacKenzie; Janet (Comumente chamado de Jenny na obra) Fraser Murray; lan Murray; e François Anselm Mericoeur d'Armagnac (Comumente chamado de Padre Anselm na obra).

Primeiramente há a personagem Claire Beauchamp, mais conhecida pelo nome de casada Claire Randall Fraser, que é a personagem feminina principal da série de livros Outlander e uma das personagens-foco deste estudo. O primeiro volume é todo narrado por ela e nas continuações há outros personagens que narram, porém, ela continua como o ponto de vista principal da narrativa.

Claire é uma mulher britânica que perdeu os pais ainda na infância e foi criada pelo seu tio Lamb, cuja profissão era ser arqueólogo. Ele a criou viajando pelo mundo nas expedições em que ele trabalhava, afinal, a pequena Claire nunca quis ir morar em um internato para estudar, então, ele acatou sua decisão e levou-a junto dele.

Anos mais tarde, Claire é enfermeira na década de 1940 em meio a Segunda Guerra Mundial e acaba se interessando muito por botânica. Pelo seu conhecimento amador das plantas, ela obtém o cargo de curandeira em 1743 (quando realiza a viagem no tempo) no Castelo Leoch e também entre o grupo de guerreiros de Dougal MacKenzie. Todavia, por causa desse mesmo entendimento de enfermagem 
e botânica as pessoas começam a acreditar que Claire é uma bruxa, pois no século XVIII não havia o tanto de conhecimento sobre plantas, remédios, procedimentos cirúrgicos, e a noção sobre saúde era muita mais precária do que a do século $X X$.

Claire se apresenta como uma mulher independente e uma esposa amorosa para seus dois maridos, Frank Randall em 1945 e Jamie Fraser em 1743. Ela demonstra ser uma mulher aventureira e corajosa ao fazer uma viagem no tempo para duzentos anos no passado, ter a opção de voltar para seu presente e mesmo assim decidir ficar no passado. Claire encara muitos perigos e risco de vida durante sua jornada, porém, em nenhum momento ela desiste. Ao contrário, ela sempre ergue a cabeça e encara o que tiver pela frente, desde se casar com um desconhecido para não morrer, assim como lutar com lobos para salvar seu amado.

Outro personagem de destaque da narrativa é James MacKenzie Fraser, mais conhecido como Jamie, que é a figura masculina principal e faz parte núcleo de 1743. Ele é um jovem guerreiro escocês nascido em primeiro de maio que obteve o título de Lorde de Broch Tuarach, a casa dos Fraser, depois da morte de seu pai e irmão mais velho. James foi muito bem-educado porque estava na linha de sucessão de pai e seu tio (terceiro na linha de sucessão de Castelo Leoch, a casa dos MacKenzie por parte da família materna).

Jamie é um homem muito inteligente e fala inglês, gaélico e francês; sabe lutar; é leal; e batalha por aqueles que ama. Ele demonstra ser um marido muito apaixonado pela sua esposa, Claire, e confia muito nela. Um exemplo dessa confiança é a cena na narrativa que Claire conta a ele que ela é de 1945 e fez uma viagem no tempo; mesmo achando essa história uma loucura, ele acredita e a ajuda a ir para Craigh na Dun para ela voltar para 1945 e voltar para seu primeiro marido.

De acordo com a obra The Outlandish Companion, Volume One, Franklin Wolverton Randall, mais conhecido como Frank Randall, é o primeiro marido de Claire Randall Fraser e faz parte núcleo de 1945. Ele é um professor universitário de História, tem grande entusiasmo sobre sua árvore genealógica e seus antepassados, e durante a Segunda Guerra Mundial trabalhou para o MI6. Os antepassados de Frank foram um dos motivos da ida dele e de Claire para a Escócia, na segunda lua de mel, quando a guerra terminou. Em Inverness, Frank descobre que é descendente de Jonathan Wolverton Randall (Black Jack).

De acordo com o site oficial da autora, Jonathan Wolverton Randall, mais conhecido como Black Jack, é um oficial britânico trabalhando para Sua Majestade e 
faz parte núcleo de 1743. O termo Black do seu apelido se refere a cor da sua alma que é negra por ele ser uma pessoa tirana, sádica e cruel. Jonathan Randall é ancestral de Frank Randall, e Claire confunde Black Jack e Frank Randall à primeira vista em 1743 por serem fisicamente muito semelhantes; entretanto, logo ela percebe que Jack não é o seu primeiro marido Frank, pois os comportamentos são opostos.

Como resultado da leitura da série Outlander, pode-se afirmar que o personagem Reverendo Reginald Wakefield trabalha na Inverness de 1945. Assim como Frank, também é interessado em genealogia e história. Foi ele quem ajudou Frank Randall a descobrir pistas de que Jonathan Randall, vulgo Black Jack, era seu parente distante. Um fato interessante na narrativa é que ele adota um menino chamado Roger, que por um acaso é descendente do filho de Geillis Duncan e Dougal MacKenzie.

Outra figura de grande relevância para este trabalho é Geillis Duncan, uma mulher intrigante, muito inteligente, e que possui bastante conhecimento sobre plantas e ervas, por isso é considerada tanto uma curandeira quanto uma bruxa em 1743. O título de bruxa acaba sendo mais relevante quando ela é mandada para fogueira para ser queimada viva por assassinar seu marido Arthur Duncan (procurador fiscal de Cranesmuir) com veneno obtido através de seu conhecimento de botânica. Quando é mandada para fogueira, Geillis está grávida, porém, não é de seu marido Arthur, e sim de Dougal MacKenzie, seu amante. A gravidez também foi um dos motivos para ela envenenar o marido.

Geillis é patriota, idealista e compactua com a rebelião jacobita apoiando-os financeiramente para tentar mudar o curso da história e evitar que a rebelião falhe como está nos livros de História. Geillis também é uma viajante do tempo, entretanto, ela vem de uma época mais no futuro que Claire: de 1968. No século XX, o nome de Geillis era Gillian e o sobrenome era Edgars, do marido Greg Edgars que ela matou, pois, acreditava que necessitava de um sacrifício para fazer a viagem no tempo.

Claire só descobre que Geillis é do futuro quando vê a marca da vacina contra varíola que Duncan tem no braço quando as duas estão em julgamento condenadas como bruxas. Então, Geillis se acusa e admite que é uma bruxa para criar uma distração, e também para ajudar Claire a se livrar do julgamento e fugir com James, que foi resgatar sua esposa. 
Um curioso fato é que a personagem Geillis Duncan foi baseada em uma bruxa real chamada Geilis Duncane, retratada em um livro escrito pelo rei James da Escócia (mais tarde James I da Inglaterra): o livro é chamado Daemonologie ${ }^{25}$. O rei escreveu esse livro sobre o julgamento de um $\operatorname{coven}^{26}$ de bruxas que tentou matá-lo usando magia negra, de acordo com as crenças dele.

Segundo as informações escritas por Gabaldon na narrativa, Dougal MacKenzie é o segundo na linha de sucessão de Castelo Leoch, tio materno de James Fraser e personagem parte do núcleo da narrativa de 1743. Ele sempre comanda os guerreiros do clã MacKenzie, pois seu irmão e chefe do clã, Colum, não pode devido a suas condições físicas provenientes de sua doença. Dougal teve um filho (Hamish MacKenzie) com sua cunhada Letitia, esposa de Colum, para gerar um herdeiro em nome do clã e suas terras.

Dougal é casado e tem quatro filhas oficialmente com sua esposa, e também cuidou de James por pouco tempo na adolescência. Além de ser um chefe muito respeitado no quesito militar de seu clã, Dougal MacKenzie é patriota e quer ajudar na volta da família escocesa Stuart para o trono britânico, por isso ele ajuda na causa jacobita. Em virtude dessa causa, Dougal arrecada dinheiro durante suas viagens para recolher imposto nas terras do seu clã e é nessas reuniões em prol dos levantes jacobitas que ele conhece Geillis Duncan, eles têm um caso amoroso, tornam-se amantes e ela engravida dele.

Ao analisar a obra Outlander: a viajante do tempo, pode-se dizer que Colum MacKenzie é tio de James Fraser por parte de sua mãe Ellen MacKenzie Fraser e personagem parte do núcleo da narrativa de 1743. Além de ser acometido pela Síndrome de Toulouse-Lautrec, o que faz ele não ter força nos ossos e não poder se exercitar para evitar fraturas, Colum é o Lorde do Castelo Leoch e chefe do clã MacKenzie. Foi Colum que aceitou Claire em suas terras como curandeira para observá-la, pois ele e o irmão Dougal supunham que ela era uma espiã britânica.

\footnotetext{
${ }^{25}$ KING, James the First of England. Daemonologie. Inglaterra: Aziloth Books. $1^{\text {a }}$ ed. 2012.

26 "O bruxo wiccano pode ser um praticante solitário ou fazer parte de um coven - grupo de bruxos com "afinidade mágica". Por tradição, um coven não pode ter mais de 13 indivíduos, número a partir do qual deve dar origem a outro grupo. Um conjunto de covens irmãos compõe um groove." (MARANHÃO Fo ${ }^{\circ}$ Eduardo Meinberg de Albuquerque (org.), 2013)
}

"Num coven forte, o liame é, por tradição, 'mais forte que o de família': a partilha espiritual, emocional e imaginativa, 'perfeito amor e perfeita confiança' são as metas". (STARHAWK, 2010, p. 82) 
Já o personagem Edward Gowan, mais conhecido como Ned, é um advogado de Edimburgo que trabalha para Colum e o clã MacKenzie ajudando a cobrar impostos, e é um personagem parte do núcleo da narrativa de 1743. Ele acaba sendo um amigo para Claire durante as viagens pelas terras escocesas dos MacKenzie. Ned ajuda Claire em seu julgamento por bruxaria advogando em favor dela e ele quase consegue soltá-la, porém, o testemunho do Padre Bain destrói as chances que ela tinha de ser solta.

Em face do cenário narrativo da obra, Padre Bain que atua em Cranesmuir, é um personagem importante para a trama de Claire em 1743, pois ele a acusa de bruxaria. Ele age de má-fé por não concordar com o conhecimento avançado de medicina que Claire tem, pois, o entendimento que se tinha de enfermagem e botânica naquela época era muito limitado, e como Claire vinha do futuro, ela trouxe uma quantidade de experiência a mais para o século XVIII.

Padre Bain testemunha no julgamento de Claire dizendo que ela o amaldiçoou e afirmou sua morte porque, além de ter um conhecimento avançado para a época e ele não concordar baseado em seus dogmas cristãos, Claire era uma mulher. Todavia, Claire só diz que ele precisaria limpar sua ferida feita por uma mordida de cachorro ou a ferida infeccionaria e ele poderia perder a perna ou até mesmo morrer.

Acerca do personagem Murtagh Fraser, pode-se afirmar que ele é um guerreiro que jurou lealdade ao clã Fraser e é um personagem parte do núcleo da narrativa de 1743. Ele é muito reservado e carrancudo, porém, é leal e genuíno com seu afilhado Jamie Fraser e sua esposa, Claire. Ele é um dos únicos no século XVIII a saber a verdade sobre a história da viagem no tempo de Claire.

No núcleo narrativo de 1743, a personagem Glenna Fitzgibbons, mais conhecida com Sra. Fitz, é a governanta de Castelo Leoch. Ela administra todo o castelo do clã MacKenzie como mordomo e cozinheira-chefe. Glenna vira amiga de Claire e a põe para auxiliar na colheita de ervas, o que ajuda Claire na função de curandeira adquirindo mais conhecimento. Sra. Fitz também é a avó de Laoghaire MacKenzie e esposa do tio de Murtagh Fraser.

Na narrativa, Laoghaire MacKenzie é uma jovem de Castelo Leoch que é neta da Sra. Fitz e que se apaixona por James Fraser, além de ser uma personagem parte do núcleo da narrativa de 1743. Laoghaire adquire uma amizade com Claire, entretanto, a amizade vira raiva e inveja devido ao interesse de James por Claire. 
Então, não satisfeita pelo casamento do casal principal, ela arma uma cilada para Claire ao dizer que Geillis a chamou em sua casa, sabendo que Geillis iria ser presa por bruxaria e que se Claire tivesse lá também poderia ser presa junto.

Uma figura de fundamental importância para a narrativa é Janet Fraser Murray. Apelidada de Jenny, ela é a irmã mais velha de James Fraser e uma personagem parte do núcleo da narrativa de 1743. Ela é casada com lan Murray e no primeiro livro já tem dois filhos, James e Margaret Murray. Ela é tão obstinada e teimosa quanto seu irmão James. Jenny é uma mulher forte, de grande coração, e administra Lallybroch (terreno de sua família), sua casa, seus filhos e o marido. Ela luta pelo que acredita e por aqueles que ama como no fragmento do livro Outlander em que ela não pensa duas vezes em ajudar Claire a resgatar seu irmão Jamie dos soldados britânicos.

É possível confirmar a partir do enredo literário, que lan Murray é amigo de infância de James Fraser e se casou com Jenny Fraser, irmã do amigo James. Além de ser um marido amoroso, um pai presente e um amigo leal, ele é um personagem secundário que faz parte do núcleo da narrativa de 1743. lan ajuda a esposa, Jenny, a administrar as terras de Lallybroch e a apoia em tudo como no momento em que ela sai com a cunhada, Claire, para salvar o irmão, Jamie. Devido a uma ferida infeccionada que adquiriu em uma batalha em Daumier, lan não tem o pedaço abaixo do joelho de uma das pernas.

Por último, porém não menos importante, há o personagem François Anselm Mericoeur d'Armagnac (Padre Anselm) que é um padre franciscano, parte do núcleo da narrativa de 1743, que ajuda Claire e James depois que eles fogem de Black Jack. Como James está muito debilitado pelo estupro e quase morte, Claire está passando por um momento difícil tentando cuidar e apoiar seu marido. Enquanto eles ficam escondidos na igreja em que o Padre Anselm atua, Claire busca força para suportar o que passa e a encontra na fé e na amizade com o padre que a presenta à Adoração Perpétua. Claire em uma confissão ao padre, conta tudo a ele sobre sua viagem no tempo e pede ajuda a ele sobre o que deve fazer.

Todas as informações e características sobre os personagens que têm relações com as cenas consideradas pertinentes que agregam dados para com este trabalho e principalmente o próximo capítulo, citados nos parágrafos anteriores são: cenas compiladas e retiradas do livro Outlander: a viajante do tempo, do livro The 
Outlandish Companion, Volume One, assim como da seção sobre personagens ${ }^{27}$ da série de livros Outlander no site oficial da autora Diana Gabaldon, tendo a mesma como escritora das três referências citadas nesse parágrafo.

${ }^{27}$ Disponível em: <http://www.dianagabaldon.com/resources/faq/faq-about-the-characters/>. Acesso em: 31 ago. 2020. 


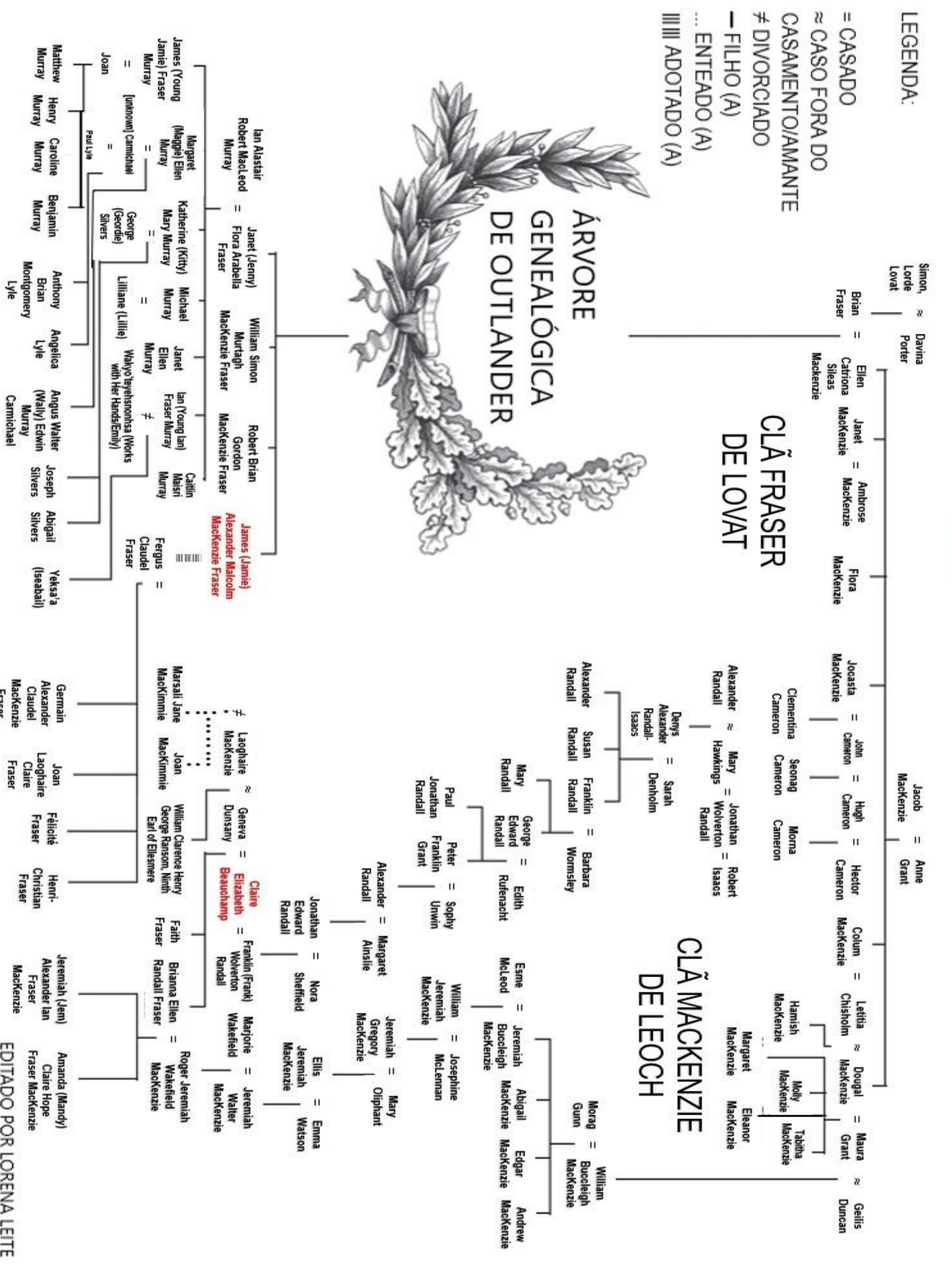




\section{Feminismo e suas 3 ondas}

Para Gonçalves (2019, p. 12), o feminismo é "um ideal e um movimento real, uma forma de pensamento e busca de ação abrangente para promover cada vez mais a igualdade de oportunidades entre mulheres e homens". Aliado a essa afirmativa e outras definições ditas por McCann (2019, p. 14), hooks (2018, p. 21), Jenainati (2007, p. 3), e Alves (1991, p. 8), é possível entendermos que o feminismo é um movimento ideológico que luta pelos direitos legais, civis e políticos da mulher. O termo Feminismo retrata todo um movimento que quer atingir uma igualdade social, política e econômica entre os sexos; e consequentemente acabar com o sexismo e opressão do homem contra a mulher. O termo é proveniente da palavra em francês féminisme e derivada do latim femĭna+ismo.

O movimento começou no século XIX, na Europa, pois as mulheres queriam o equilíbrio dos direitos políticos e sociais entre os sexos. Elas queriam ter as mesmas oportunidades que os homens tinham no quesito de leis, trabalho, voto, liberdade, entre outros. As mulheres lutaram contra o patriarcado, contra a desigualdade social e de gênero para mudar seu próprio futuro e das demais mulheres que viriam a nascer posteriormente. Embora não tenha sido declaradamente uma feminista, Wollstonecraft (1988, p.45) procurou semear ao longo de sua vida ideias que hoje podem ser lidas como feministas:

É hora de fazer uma revolução sobre a conduta da mulher - hora de resgatar a dignidade perdida - e fazê-las, como parte da espécie humana, trabalhar para reformá-las e, assim, reformar o mundo. (WOLLSTONECRAFT)

Entende-se por patriarcado a relação de poder entre homens e mulheres em que a mulher é subordinada aos interesses do homem por serem consideradas fracas por causa da diferença biológica entre os dois sexos. O patriarcado está incorporado em todas as culturas, costumes, políticas, e principalmente nas religiões, utilizando-se de uma dominação machista e sexista dos povos para camuflar um reducionismo biológico (refletido por Arán [2006] a partir das críticas de Freud e Lacan).

Como resultado de uma das maiores revoluções da história mundial, a luta das mulheres pelos seus direitos modificou inegavelmente o campo político, social e cultura de diversos povos. O peso e efeito que o feminismo carrega faz cada dia mais as mulheres pesquisarem sobre história, refletir sobre ela e querer modificá-la 
para que futuras gerações não precisem passar pelas injustiças que muitas mulheres passaram nos séculos passados.

Digo revolução pela possibilidade de ruptura na história das mulheres de sua condição milenar de dominação, porém admito que, longe de ser uma conquista assegurada de direitos políticos, esse movimento possibilitou sobretudo uma mudança em suas vidas, em suas escolhas profissionais, em seus desejos, e em suas relações amorosas, que podem, hoje, seguir diferentes caminhos, não necessariamente traçados pelo que no século passado se anunciou como sendo a sua "natureza". (ARÁN, 2006, p. 15)

O dia 8 de março é conhecido como o Dia Internacional da Mulher devido a uma luta constante a favor dos direitos trabalhistas das mulheres que trabalham em fábricas no século XIX. As operárias não ficaram mais em silêncio e decidiram fazer uma manifestação a favor da redução do horário de trabalho, que na época era de 12 horas, e manifestando também por salários mais justos em relação à carga horária e ao salário que os homens operários ganhavam. Essa luta durou décadas, porém, os esforços daquelas mulheres abriram os olhos de outras a lutarem por seus direitos, e com isso o dia 8 de março se tornou um dia de homenagem às mulheres.

A autora Diana Gabaldon mostra, com as personagens femininas, que mesmo que a narrativa de Outlander: a viajante do tempo seja decorrida em dois momentos no passado (anos de 1945 e 1743) em relação ao ano em que foi escrito (1991), as atitudes contemporâneas dessas mulheres de 1743 são notórias. Há muitos vínculos com a época atual, principalmente em questão de não dominação pelo homem, profissão, liberdade de expressão, entre outros.

Todavia, a narrativa também mostra a visão mais moderna de uma escritora sobre um querer feminista para o passado. Ou seja, Gabaldon criou uma personagem (Claire) que vivia em 1743, porém, Claire tinha atitudes e a visão de mundo de uma mulher que vivia em 1991, e em vez de retirar essas atitudes modernas e encaixar a personagem nas atitudes pré-estabelecidas para a época em questão, a autora preferiu fazer com que Claire fosse ambientada primeiramente em 1945, fosse enfermeira e que viajasse no tempo para 1743.

A escolha da autora por realocar a personagem no tempo com ideais feministas nos mostra um desejo de não oprimir e calar a personagem feminina, uma vez que era recorrente a mulher não ter poder de fala no século XVIII. Gabaldon mudou toda uma ideia primordial da narrativa e faz hoje este trabalho de conclusão 
de curso ser válido. Assim, com a narrativa de Outlander: a viajante do tempo, é possível a leitura de que a autora:

Resgata, através do romance histórico, a mulher que sempre fora excluída do discurso histórico, como forma de reivindicar o passado em nome daquelas que foram silenciadas e marginalizadas pela historiografia. (MONTEIRO, 2003, p. 18).

Esse contexto de narrativas escritas no século $X X$ e $X X I$, porém ambientadas em séculos anteriores e com personagens tendo atitudes contemporâneas não é uma novidade. Um exemplo seria a obra Fair Exchange de Michèle Roberts que foi publicada em 1999 e que tinha personagens femininas do século XIX que estudaram para terem uma profissão, foram mães solteiras e lutavam pelos direitos das mulheres. Segundo MONTEIRO (2003, p. 15),

Apesar de o romance Fair Exchange ambientar-se no passado, são
evidentes as conexões com a atualidade, donde a presença de novas
imagens da mulher, decorrentes de sua atuação profissional, bem como de
organizações familiares típicas da contemporaneidade, assinaladas pela
existência de mães e pais solteiros.

Segundo a obra O que é lugar de fala? de Djamila Ribeiro (2017), filósofa e ativista feminista, entende-se por lugar de fala: o ato de fala da pessoa que está incluída dentro do contexto em que se fala, e essa fala representativa serve para entender as realidades que estão explicitas e implícitas dentro do contexto inserido. Entretanto, Ribeiro acredita que toda fala representativa deve ser embasada teoricamente para não banalizar o assunto de extrema importância para grupos da minoria, pois o lugar de fala tem como objetivo destacar outras realidades e pontos de vista diferentes da grande hegemonia.

Além disso, é de notável relevância entender que lugar de fala não é necessariamente sobre uma fala individual, e sim uma fala com destaque no coletivo, porém que não invalida o entendimento individual sobre o contexto. Neste trabalho de conclusão de curso, o lugar de fala pertence ao feminismo, ou seja, pertence às mulheres, pois só elas podem exteriorizar o que passam. Por causa da existência de uma diversidade de realidades em que a mulher vive é que existem diversas ramificações do feminismo, assim pode-se focar melhor nos contextos de cada coletivo dentro do movimento feminista.

Em virtude do feminismo, as mulheres do século $\mathrm{XXI}$ conseguem enxergar valores patriarcais enraizados na criação e se dedicam a mudar essas atitudes automáticas que são passadas de mães para filhas. Um desses valores patriarcais é 
a maternidade ${ }^{28}$, que nos dias atuais já não é vista como exclusiva da mãe, e sim como a união dos pais para instruir a vida que está sendo gerada.

Entretanto, "enquanto mulheres têm suas vidas transformadas em todos os aspectos, os homens poucas mudanças sofrem com a circunstância correlativa da paternidade" (MONTEIRO, 2003, p. 23). Então, como uma solução para essa visão arcaica do papel do homem dentro da maternidade/paternidade, as mulheres lutam em favor de direcionar outras mulheres a não aceitarem o pai da criança como mero coadjuvante na criação dos filhos e para que o ele seja mais ativo e entenda que é uma parte fundamental no crescimento de uma criança.

O movimento ideológico feminista também luta contra o estereótipo da dualidade da mulher como predestinada para casar e mulher que não serve para casar, ou seja, a dualidade da mulher mãe e a mulher libertina. Segundo a visão que o feminismo pretende desconstruir, a mulher certa para casar ou ser mãe seria aquela que é criada de modo tradicional, com visões somente para a maternidade e casamento.

Contudo, a mulher que não serve para casar ou libertina seria aquela que é independente, que tem visões do próprio futuro além de maternidade e casamento, como estudar e ter emprego; lembrando que "[...] no século XVIII a maioria das mulheres tinha na Europa ocidental pouca liberdade nos campos econômico e intelectual.", como Monteiro (2003, p.19) escreve no livro Dialogando com Culturas: Questões de Memória e Identidade.

Atualmente, com toda a independência, liberdade de expressão, busca por salários iguais, entre outros, que as mulheres almejam, é possível perceber uma evolução na luta feminista, sendo essas mulheres a mulher mãe ou a libertina como costumeiramente o patriarcado as divide. Um exemplo seria que a mulher mãe também estuda e tem emprego, entretanto, ela ainda é criada com valores tradicionais como casar virgem, não sair para bares sozinha, tomar conta da criação e educação dos filhos, cuidar das tarefas domésticas, entre outros. Segundo o patriarcado, a mulher libertina tem vários relacionamentos e relações sexuais com parceiros diversos, sai para bares sozinha, quer um companheiro que a ajude nas

\footnotetext{
${ }^{28}$ Neste trabalho entende-se por valores patriarcais da maternidade/paternidade aqueles em relação a laços heterossexuais.

"Dentro do patriarcado, laços heterossexuais eram formados baseados na ideia de que as mulheres, por serem do gênero em contato com sentimentos de cuidado, dariam amor aos homens, e como recompensa, os homens, por estarem em contato com poder e agressão, seriam provedores e protetores." (HOOKS, 2018)
} 
tarefas domésticas e na educação dos filhos ou até tem filhos por conta própria, entre outros.

Esse é um dos motivos de haver tanto preconceito quanto a mulher se declarar feminista, pois a independência dela e escolha de suas ações, na visão de pessoas conservadoras, agride os valores tradicionais, principalmente no que tange ao fator casamento. Hoje em dia, a mulher não é mais obrigada a casar e constituir família, ela assim o faz se quiser. Um dos objetivos do movimento feminista é exatamente esse, dar à mulher a liberdade de escolha do que quer e do que não quer fazer, a liberdade do seu presente e futuro.

Uma ideia preconceituosa que se tem do movimento feminista é que todo o movimento é uma máscara para uma revolução de dominância das mulheres sobre os homens, como se as mulheres não quisessem um equilíbrio entre os sexos e sim, serem superiores. Essa ideia de soberania das mulheres parece vir do medo que o patriarcado tem, uma crença de que as mulheres querem uma espécie de vingança pelos anos de opressão em que viveram.

Ao contrário de Rousseau, que pregava que as mulheres deveriam ter a mesma educação dos homens, para que, quanto mais se assemelhassem ao nosso sexo, menos poder tivessem sobre nós, Wollstonecraft desejava às mulheres não poder sobre os homens, mas sobre si mesmas. (MONTEIRO, 2003, p. 21)

\subsection{A primeira onda}

A primeira onda do movimento feminista teve início no século XVIII com as manifestações de insatisfação das mulheres por não terem direitos de cidadania. Os primeiros manifestos deram-se através de livros e periódicos escritos por mulheres a favor do direito de estudar e trabalhar. Com o passar dos anos e com a gradual aquisição de direitos, as mulheres passaram a ter que lutar em nome de uma educação mais ampla e o direito de uma profissão justa através dos seus direitos trabalhistas e de cidadania. Nessa primeira onda, as mulheres começaram a se organizar e a realizar passeatas, entretanto, ainda não era discutida a questão do patriarcado e opressão.

Mary Wollstonecraft é uma das pioneiras do movimento feminista e lutou arduamente pela busca da educação das mulheres e pelos direitos igualitários da mulher se profissionalizar. Um exemplo dessa luta é a obra Thoughts on the Education of Daughters (1787). Wollstonecraft, influenciada pelas ideias das 
Revoluções Americana e Francesa, acreditava que a mulher deveria participar integralmente como cidadãs tendo direitos e deveres. Então ela publicou $A$ Vindication of the Rights of Woman (1792) onde critica os problemas da distinção e opressão entre os gêneros masculino e feminino. Nela, Wollstonecraft defende que:

\begin{abstract}
A educação das mulheres tem-se aperfeiçoado, entretanto elas ainda são não somente consideradas o sexo frívolo, mas também ridicularizadas por escritores que tentam melhorá-las através da sátira ou da instrução. Reconhece-se que passam os primeiros anos de suas vidas adquirindo conhecimento superficial, enquanto a força do corpo e da mente é sacrificada por noções libertinas de beleza, pelo desejo de estabeleceremse - a única forma que a mulher pode ascender no mundo - no casamento [...]. Certamente, esses seres frágeis servem para 0 seraglio ${ }^{29}$. (WOLLSTONECRAFT, 1988, p. 10)
\end{abstract}

Foi na primeira onda do movimento feminista que algumas mulheres escritoras utilizaram-se da literatura ficcional e não-ficcional para falar das preocupações femininas, expondo o desejo de independência das mulheres tanto explicitamente quanto subentendidamente. Dois dos mais importantes exemplos são as escritoras canônicas Jane Austen (1775-1817) e Virginia Woolf (1882-1941).

A escritora inglesa de narrativas ficcionais Jane Austen foi inspirada pela escritora e filósofa Mary Wollstonecraft e o livro A Vindication of the Rights of Woman, e por isso é possível uma leitura com o olhar feminista nas suas heroínas nas suas obras literárias, mas tudo subentendido. Austen criticou em seus livros a etiqueta que as mulheres eram obrigadas a aprenderem, a forma em que as mulheres eram levadas a parecerem ignorantes e não exporem suas opiniões como se fossem seres não racionais, e o casamento como único meio de segurança social e econômica. Algumas dessas obras de Jane Austen são Orgulho e Preconceito (1813), Mansfield Park (1814) e Emma (1815).

Nessas narrativas, Austen foca bastante em críticas sociais. Algumas dessas críticas eram voltadas para como as mulheres eram induzidas, pelos padrões patriarcais, a se casarem, e a terem um casamento financeiramente vantajoso. As mulheres no século XVIII viviam para um bom casamento; toda a sua vida, desde o nascimento, era voltada para encontrar um bom partido. Austen refletiu a sociedade na qual vivia em suas obras, e ao mesmo tempo, tentou mudar os pensamentos e comportamentos das suas heroínas, algo que hoje lemos como um ato feminista.

\footnotetext{
${ }^{29}$ Seraglio é um lugar no palácio Otomano onde as mulheres do harém viviam.
} 
As protagonistas nas narrativas de Jane Austen eram mulheres fortes, independentes, determinadas, questionadoras e nada submissas e passivas. Elas não deixavam que os pensamentos do senso comum da época atrapalhassem em suas próprias opiniões acerca do que queriam, como queriam e quando queriam. As heroínas de Austen tentavam buscar igualdade entre a mulher e o homem, assim, desconstruindo a visão hierárquica que o patriarcado construiu ao longo dos séculos.

A escritora e editora inglesa de obras ficcionais e não-ficcionais Virginia Woolf utilizou suas obras literárias para falar explicitamente do feminismo. Ela foi inspirada pelo movimento sufragista (explicado no final deste subcapítulo) a escrever sobre as problemáticas em que as mulheres viviam. Algumas obras de Woolf de grande importância ao feminismo são Senhora Dalloway (1925), Orlando (1928), Um teto todo seu (1929), Profissões para mulheres (1931) e As mulheres devem chorar... Ou se unir contra a guerra (1938).

A narrativa de Senhora Dalloway trata da opressão exercida pelo homem sobre a mulher, e que essa desigualdade entre ambos os sexos faz com que a mulher não tenha muito espaço na sociedade, principalmente em se tratando de espaço intelectual, pois as mulheres não tinham direitos a uma educação acadêmica no começo do século XX. Já a narrativa de Orlando trata sobre um personagem que é imortal e que ao longo da sua vida o personagem muda seu gênero e obtém experiências de acordo com a persona que adquire.

Em Um teto todo seu, Woolf discorre sobre a dificuldade que as mulheres têm para conquistar o mesmo sucesso editorial que um homem; ela também critica como as mulheres são impedidas de entrar em espaços sociais e culturais como restaurantes, bibliotecas e universidades. Já em Profissões para mulheres, a escritora compila diversos ensaios sobre como a visão tradicional que era imposta à mulher dificultava o sexo feminino em estar no mercado de trabalho, e também critica a mulher como somente dona de casa. Virginia Woolf, no livro As mulheres devem chorar... Ou se unir contra a guerra, discorre sobre o patriarcado e o militarismo.

O movimento sufragista começou no século XIX e se estendeu até o século $\mathrm{XX}$ quando as mulheres começaram a ser reconhecidas como cidadãs e tiveram seu direito a voto legalizado. Segundo McCann (2019), o movimento foi um protesto a favor das mulheres sufragistas que queriam ter seus direitos reconhecidos igualmente aos dos homens que lutaram pelo sufrágio universal. 
O sufrágio universal visava melhores condições trabalhistas, luta pelos direitos de cidadania, pela democracia, e direito de voto da classe social não burguesa. As mulheres operárias somente queriam ser social, econômica e politicamente legitimadas como os homens daquela época, porém, demorou quase um século para que elas conseguissem os tão sonhados direitos. Por esse motivo, o movimento sufragista das mulheres é um marco para o movimento feminista.

\subsection{A segunda onda}

Segundo Gonçalves (2019), a segunda onda do movimento feminista teve início no século XX. Além de toda a luta sobre a educação, trabalho e voto, essa época também foi marcada pela luta contra opressão do patriarcado, a luta a favor da sexualidade e da identidade da mulher. As lutas encaminhadas pela primeira onda feminista foram atualizadas para, por exemplo, a mulher não ter emprego só como forma de contribuição com os pagamentos de contas da casa, e sim ter uma carreira sólida e de sucesso, um desejo de se profissionalizar, um emprego que seja parte de sua identidade e independência, entre outros.

O feminismo passa a lutar a favor da recriação de uma identidade própria. Essa identidade seria fora da visão do masculino por causa do reducionismo biológico imposto historicamente pelo patriarcado, uma hierarquia sexual em que o homem é superior à mulher e ela deve ser submissa a ele. Uma das principais mudanças, além do emprego, é o divórcio (No Brasil ${ }^{30}$, a partir da década de 1970). Segundo McCann, a ação legal de se divorciar é um ato de liberdade da mulher em relação ao sofrimento que suportava no casamento devido à submissão, opressão, violência, entre outros.

Por tantos anos se enxergando através do olhar do homem, muitas mulheres passaram a acreditar que elas mereciam e deviam exercer o papel de bela, delicada e submissa, um papel de opressão. A luta das feministas é fazer com que as mulheres não sejam mais silenciadas e também não se enxerguem mais como fracas, passivas, frágeis, dependentes e obedientes.

Com essas mudanças drásticas da mulher se divorciando, algumas vezes nem se casando, e encontrando uma profissão, a base do patriarcado começa a se

\footnotetext{
${ }^{30}$ Disponível em: <http://www.planalto.gov.br/ccivil_03/leis//6515.htm>. Acesso em: 30 out. 2020.
} 
desestabilizar porque a dita família tradicional começa a não existir. Além disso, a nova visão de família começa a se formar. A família passa ser moderna, a mulher trabalha igual ao marido (se tiver um marido) e mais atualmente no século $\mathrm{XXI}$, o marido faz as tarefas domésticas igualmente com a esposa; a mulher é mãe solteira, seja por opção ou por abandono paterno; fora que a contemporaneidade dos tempos nos traz a presença da família monoparental ${ }^{31}$ que desestabiliza de vez a família convencional e tradicional construída dentro dos padrões patriarcais.

As pílulas contraceptivas foram um grande marco do movimento feminista, pois com a fabricação das pílulas anticoncepcionais, as mulheres ganharam uma independência maior sobre seu próprio corpo e adquiriram o direito à escolha de querer ou não engravidar. Contudo, ainda há muitos direitos sobre si mesmas que as mulheres ainda não conseguiram, como: fazer o procedimento de ligadura das trompas e realizar um aborto (fora as exceções previstas em lei).

Para fazer o procedimento de ligadura, no Brasil, é preciso ter a assinatura do marido como forma de autorização, ter uma quantidade mínima de filhos e uma certa idade mínima para fazer a cirurgia. Para realizar um aborto é ainda mais complicado, no Brasil, por exemplo, o aborto só é legalmente concedido em casos de estupro, risco à saúde da gestante e quando o bebe que está sendo gerado tem anencefalia ${ }^{32}$. Atualmente, o aborto é uma das mais polêmicas lutas do movimento feminista, porém, ele é visto pelo feminismo como um ato de saúde pública.

\begin{abstract}
A proposta do movimento feminista não é a utilização do aborto como método contraceptivo, e sim como último recurso ao qual as mulheres devem ter seu direito assegurado, no sentido de garantir que a maternidade seja o resultado de uma opção consciente e não de uma fatalidade biológica. (ALVES, 1991, p. 61)
\end{abstract}

Todavia, as mulheres conquistaram o principal ponto: a visão da mulher como ser reprodutivo e não sexual começou a ser desmistificada. $E$ foi a partir da luta pela sexualidade feminina que conquistas como os métodos contraceptivos existem hoje em dia, ajudando a mulher a escolher se quer engravidar ou ajudando-a na organização e programação para a gravidez. Além disso, com a visibilidade da

\footnotetext{
${ }^{31}$ Utilizei o termo monoparental ao invés do termo homo parental porque esse é o termo usado pelo autor Luiz Mello na obra Novas famílias: Conjugalidade homossexual no Brasil contemporâneo (2009) que pesquisei para falar o assunto.

${ }^{32}$ Anencefalia é a má formação do cérebro durante a formação embrionária causando uma ausência total do encéfalo e da caixa craniana. As crianças que nascem anencefálicas tem poucos anos de sobrevivência.

Disponível em: <https://www.febrasgo.org.br/pt/noticias/item/138-anencefalia-e-poder-judiciario>.

Acesso em: 30 set. 2020.
} 
sexualidade feminina, as mulheres passaram a não serem tão reprimidas em relação ao seu próprio prazer, e a entenderem melhor seus corpos.

Simone Beauvoir é considerada uma referência do feminismo contemporâneo, uma grande influência na luta pela emancipação feminina, e é a pioneira da segunda onda do feminismo com o livro seminal O Segundo Sexo (1949) que fala sobre o sexo feminino sendo o outro em relação ao sexo masculino. Nesta obra, Beauvoir põe em xeque a construção social patriarcal de que a opressão direcionada às mulheres era porque elas tinham nervos frágeis, cérebro menor e órgãos reprodutivos diferentes ao do homem.

$\mathrm{Na}$ obra O Segundo Sexo, Beauvoir mostra diversas perspectivas de definição da mulher, e a partir dessas perspectivas, a autora escreve sua interpretação do feminino. Ela compõe sua crítica ao desconstruir a afirmação de que as já mulheres nascem femininas com base na famosa frase "Ninguém nasce mulher: torna-se mulher" (BEAUVOIR, 2009, p. 266).

E com essa firmação, Beauvoir desconstrói todo um ideal patriarcal histórico de opressão e submissão da mulher a partir do sexo biológico e do casamento. Para a escritora, o casamento era a forma de prender a mulher deixando-a dependente do homem através de toda a concepção de que a mulher tem que cuidar do lar, do marido e dos filhos, e assim a mulher não teria a percepção de que se ela quisesse, poderia ser muito mais do que só uma esposa, mãe e dona de casa.

Ainda no século $X X$, ser dona de casa não era visto como um emprego, e sim como algo obrigatório para toda esposa. Contudo, cuidar da casa era um tipo de trabalho pesado e repetitivo e, que ainda por cima, não era remunerado. Por esses motivos, Beauvoir acredita que o trabalho doméstico feito como algo obrigatório pela esposa é o mesmo que o trabalho clandestino e escravo.

\subsection{A terceira onda}

A terceira onda do movimento feminista, teve início no final do século $X X$ e continuidade no século XXI. Além de toda a crítica sobre identidade, educação, sexualidade, trabalho, opressão, voto, e patriarcado, foram também agregados à luta: a denúncia contra a violência física, econômica e psicológica que as mulheres sofrem; e o pensamento de não só ser proletariada, mas líderes e autoridades no local de emprego, e empreendedoras. 
Na relação entre mulheres e homens no trabalho, havia discrepância no quesito de qual emprego a mulher poderia exercer e quais posições ela ocuparia dentro do ambiente profissional. Por consequência da luta feminista, as mulheres conseguiram diminuir a discriminação e começaram a exercer cargos mais altos, fazendo com que o século XXI entrasse na história com mulheres governando países.

Alguns exemplos de mulheres líderes mundiais são: Dilma Rousseff como presidente do Brasil, Cristina Kirchner alternando como presidente e vice-presidente da Argentina, Michelle Bachelet como presidente do Chile, Angela Merkel como chanceler da Alemanha, Helen Clark como primeira-ministra da Nova Zelândia, Hillary Clinton como Secretária de Estado dos Estados Unidos, Laura Chinchilla como presidente da Costa Rica, Julia Gillard como primeira-ministra da Austrália, Indira Gandhi como primeira-ministra e Pratibha Patil como presidente da Índia, Ellen Johnson-Sirleaf como presidente da Libéria, Christine Lagarde como presidente do Banco Central Europeu e presidente do Fundo Monetário Internacional (FMI), entre outras.

As mulheres têm alcançado mais protagonismo na sociedade através da resistência em continuar lutando pelos seus direitos que the foram negados desde os séculos primórdios. Assim, exigem respeito, liberdade de expressão, buscam independência, igualdade política, salarial, acadêmica e social, empatia e indiscriminação.

O feminismo possibilitou o questionamento do poder atribuído ao homem e assim distribuí-lo para as mulheres, tentando gerar equilíbrio entre os sexos e autonomia de escolhas sociais. O feminismo ainda clama por mudanças sociais, pois, o papel submisso atribuído historicamente à mulher ainda persiste e, infelizmente, é proferido por pessoas preconceituosas e alienadas por conceitos patriarcais ultrapassados e arcaicos. Um dos possíveis fatores que gera tantos casos de violência contra as mulheres são pensamentos obsoletos como a necessidade de praticar violência física, de dependência econômica e de abuso psicológico, pois há homens que ainda se acham superiores e acreditam que as mulheres devem ser submissas e obedientes.

A violência física se caracteriza como espancamentos, cárcere privado, agressões, estupros e assassinatos (feminicídio). Todas essas violências contra a mulher demoraram a serem expostos, principalmente, os de violência doméstica que 
são causadas pelos cônjuges das mulheres que são vítimas. O movimento feminista luta pelo direito da mulher poder se divorciar de seus agressores, pelo direito a ter a guarda legal dos filhos, direito a abrigos e lugares de apoio emocional e psicológico para mulheres agredidas, e luta também para que os agressores sejam punidos judicialmente.

Antigamente, comprovar essas agressões algumas vezes era difícil e caro, assim, muitas mulheres não denunciavam a polícia, desistiam no meio do processo, ou até mesmo perdiam a causa na justiça. Muita coisa melhorou nos últimos dois séculos em vários países em relação a leis de punição a agressores e leis de proteção a mulher, porém, as mulheres ainda continuam sendo agredidas e mortas todos os dias. É uma luta que ainda não acabou e precisa continuar a ser pautada em todas as mídias de comunicação para ser combatida e não ser esquecida.

Já a violência psicológica se caracteriza como ameaças, constrangimento, manipulação e humilhações que geram baixa autoestima, depressão, baixa auto confiança, dano emocional, insegurança, stress e ansiedade na mulher; bem como a proibição de estudar.

A violência econômica se caracteriza como tomar todos os bens da mulher; pegar o salário inteiro dela sem deixá-la utilizar o dinheiro pelo qual trabalhava; não deixar que a mulher compre nada pessoal; exigir senhas dos cartões e fazer compras no nome da mulher sem autorização, e outras formas de chantagens e humilhações feitos pelo cônjuge que abusa do poder monetário que exerce sobre a mulher que ganha menos ou que não trabalha.

Todavia, as mulheres estão se tornando muito mais conscientes sobre a violência que sofrem e presenciam. Em relação ao passado, hoje elas têm mais coragem de denunciar, pois, há leis que as protegem. Um exemplo é que no ano de 2008, após muitas acusações, o estupro como arma de guerra foi oficialmente anunciado pela ONU (Nações Unidas) como crime.

Estudos referentes à guerra da Bósnia, de 1992 até 1995, indicam que o estrupo foi uma medida usada pelos militares sérvios para limpar etnicamente o país ao engravidar as mulheres e para forçar essas mulheres bósnias a deixarem os locais em que viviam. Como diz McCann (2019, p. 279) no livro O livro do feminismo:

As circunstâncias facilitadoras (da guerra) incluem o colapso da lei durante o conflito e a cultura militar hiper masculinizada, na qual o estupro coletivo é um exercício de 'camaradagem'. As consequências desse tipo de estupro incluem degradação, intimidação, trauma psicológico, propagação de doenças e gravidez. 
No Brasil, há a Lei do Feminicídio ${ }^{33}$ (Lei 13104 de 9 de março de 2015) que diz que no caso de qualquer mulher que perca a vida ou é levada a cometer suicídio em consequência de abusos, violência e discriminação; o homicídio se torna hediondo e qualificado com previsão de 12 a 30 anos de prisão.

Muito conhecida pela mídia no Brasil, a Lei Maria da Penha ${ }^{34}$ (Lei 11.340 de 7 de agosto de 2006), diz que todos os casos em que ocorram crimes de violência doméstica e intrafamiliar sucede em pena até 3 anos de prisão. Além disso, há a Central de Atendimento à Mulher ${ }^{35}$ — Ligue 180 (Decreto 7393 de 15 de dezembro de 2010) que ajuda no serviço de escutar e acolher vítimas de violência contra a mulher, que igualmente denuncia os crimes e atua em outros 16 países. Há também as Delegacias de Atendimento à Mulher (DEAM) ${ }^{36}$ que cuidam especificamente de crimes contra a mulher; há a Casa da Mulher Brasileira ${ }^{37}$; entre outros serviços especializados de atendimento à mulher ${ }^{38}$.

A partir da consciência de classe, sexualidade, gênero e raça, o movimento feminista desde a segunda onda criou ramificações que lutam especificamente pelas mulheres que estão inseridas em determinados contextos, realidades, e que não se sentiam representadas pelo movimento principal porque tal movimento era comandado, majoritariamente, por mulheres de classe média, brancas e héteros.

Como o movimento feminista foi polarizado por muito tempo nas Américas e na Europa, as lutas desse grupo ideológico acabaram sendo voltadas às questões ocidentais, principalmente, referentes às mulheres, como dito anteriormente, de classe média, brancas, héteros, cristãs e protestantes. Por não se sentirem representadas por tais mulheres supracitadas, as mulheres, em países não

\footnotetext{
${ }^{33}$ Disponível em: <http://www.planalto.gov.br/ccivil_03/_ato20152018/2015/lei//13104.htm\#: :text=LEI\%20N\%C2\%BA\%2013.104\%2C\%20DE\%209,no\%20rol\%20dos $\% 20$ crimes\%20hediondos>. Acesso em: 30 set. 2020.

${ }^{34}$ Disponível em: <http://www.planalto.gov.br/ccivil_03/_ato2004-2006/2006/lei//11340.htm>. Acesso em: 30 set. 2020.

${ }^{35}$ Disponível em: <http://www.planalto.gov.br/ccivil_03/_ato2007-2010/2010/decreto/d7393.htm>. Acesso em: 30 set. 2020.

${ }^{36}$ Disponível em: <https://www.gov.br/mdh/pt-br/navegue-por-temas/politicas-paramulheres/arquivo/arquivos-diversos/acesso-a-informacao/perguntas-frequentes/violencia/o-que-edelegacia-especializada-no-atendimento-a-mulher-deam>. Acesso em: 30 set. 2020.

${ }^{37}$ Disponível em: <https://www.gov.br/mdh/pt-br/navegue-por-temas/politicas-paramulheres/arquivo/assuntos/violencia/programa-mulher-viver-sem-violencia/servicos-disponiveis-nacasa-da-mulher-brasileira>. Acesso em: 30 set. 2020.

38 Disponível em: <https://www12.senado.leg.br/institucional/omv/acoes-contra-violencia/servicosespecializados-de-atendimento-a-mulher>. Acesso em: 30 set. 2020.
} 
ocidentais começaram a se mobilizarem a favor de um protagonismo baseado na realidade em que vivem.

Como exemplo de feminismo não ocidental temos o feminismo islâmico que estimula a igualdade da mulher e do homem no Islã. O Musawah ${ }^{39}$ é um grupo formado por muçulmanas que lutam a favor dos direitos das mulheres em países que tem o Corão como seu livro sagrado, um exemplo da luta desse grupo, é uma nova interpretação do Corão de uma forma que não seja voltado para um entendimento patriarcal.

Outro exemplo da luta das mulheres muçulmanas, em uma perspectiva mundial, é a escolha de usar ou não o hijab, niqab, burca, entre outros vários tipos de véus e vestimentas referentes à cultura islâmica 40 ; e também a discussão se esses tipos de vestimentas podem ser considerados como um símbolo de opressão contra a mulher ou simplesmente uma vestimenta cultural.

O feminismo indiano a luta pela eliminação da questão do casamento infantil; crimes por dote; o aumento da maioridade; a violência policial contra mulheres; legalização do estupro, assédio sexual e violência (tantos em locais públicos como privados) como crime; aborto seletivo; e o banimento da prática do sati que é uma imolação da mulher viúva, ou seja, a ação da esposa se jogar na pira funerária do marido morto e se queimar viva com o corpo.

Com a homossexualidade saindo do código penal, e do código internacional das doenças pela OMS (Organização Mundial da Saúde) em 1990, e também entrando no código civil, os debates a cerca desse grupo ganharam mais visibilidade, possibilitando em muitos países o reconhecimento jurídico da monoparentalidade e da união homoafetiva. O que possibilitou as lésbicas aderirem ao movimento feminista e a lutarem por seus direitos.

Então, com uma maior evidência da homossexualidade e do feminismo, as lésbicas puderam, finalmente, desviar de toda uma expectativa social patriarcal em casarem e terem filhos com homens; diminuir a homofobia; penalizar quem comete atos preconceituosos; não sofrerem ameaças nem violências físicas e sexuais por causa de sua orientação; entre outras causas.

\footnotetext{
${ }^{39}$ Disponível em: <https://www.musawah.org/>. Acesso em: 7 out. 2020.

40 Disponivel em: <https://iqaraislam.com/por-que-as-mulheres-muculmanas-usam-veu>. Acesso em: 7 out. 2020.
} 
O preconceito com as lésbicas se dá, principalmente, porque ainda se tem um pensamento cristalizado de que a pessoa que nasce com um determinado sexo biológico tem que sentir atração pelo sexo biológico oposto. Além de que:

[...] a sociedade tem o homem como dominador e a mulher como submissa desde os tempos primórdios entre a maioria das culturas em todos os continentes porque a sociedade se constitui a partir da troca de mulheres para a reprodução e as mulheres acabaram no lugar de objetificação e inferiorização, uma construção social das relações de poder no sistema de hierarquia entre os sexos passível de mudanças. (MONTEIRO, 2003)

Em relação ao feminismo trans, é possível a leitura a partir do livro A História da Sexualidade Volume I (Foucault, 1976) de que a sexualidade é construída pela sociedade e não um fato biológico. Tal movimento luta em favor de ter os gêneros, pronomes e nomes de mulheres trans ${ }^{41}$ reconhecidos social e legalmente, luta também contra a misoginia ${ }^{42}$, além disso, elas também têm que lutar contra feministas que são a favor da representatividade do movimento somente por mulheres cis gênero ${ }^{43}$. Elas advogam em prol de não serem marginalizadas e violentadas, como também em prol a liberdade de expressão e direitos legais, sociais, trabalhistas e cuidado médico como quaisquer mulheres.

O feminismo negro foi formado a favor de combater o patriarcado e o racismo, principalmente, o racismo vindo de dentro do movimento feminista que era majoritariamente branco. Como disse bell hooks (MCCANN, 2019, apud): "Enquanto as mulheres estiverem usando poder de classe ou de raça para dominar outras mulheres, a irmandade feminista não pode existir plenamente". O feminismo negro só foi possível ser formado depois da abolição da escravatura, entretanto, mulheres negras como Sojourner Truth (1797 - 1883) e Harriet Tubman (1822 - 1913), ambas nascidas escravas, lutaram ativamente em favor das mulheres e da abolição da escravatura. Elas lutaram em prol dos negros e mulheres terem melhores condições sociais e legais.

O discurso Ain't I A Woman? (1851) de Truth, inspirou milhares de mulheres negras e é considerado um marco na história do feminismo negro. Nele, Sojourner Truth critica a fala de um homem branco que diz que mulheres não merecem ter

${ }^{41}$ Entende-se por trans gênero, segundo o glossário do livro O livro do feminismo, pessoa cuja identidade de gênero difere da que Ihe foi atribuída ao nascer, no caso da mulher trans, o gênero atribuído ao nascer seria masculino, porém, ela se identifica como gênero feminino.

42 Entende-se por misoginia, segundo o glossário do livro O livro do feminismo, o ódio, desprezo e preconceito entranhado dos homens pelas mulheres.

43 Entende-se por cis gênero, segundo o glossário do livro $O$ livro do feminismo, pessoa cuja identidade de gênero corresponde ao que Ihe foi atribuído ao nascer. 
privilégios porque o intelectual delas são inferiores ao dos homens e porque Deus criou Jesus como homem, então, ela responde que até Cristo veio de uma mulher.

Logo após a abolição, as mulheres negras continuaram a lutar não só pelo seu direito como mulher, mas, como mulher negra, já que sofrem duplamente de preconceitos. Como as mulheres negras não tinham direito a uma educação, elas não se sentiam representadas pelas brancas que já tinham esse direito e estavam lutando por mais avanços. Então, elas se juntaram para lutar por direitos reprodutivos e contra o preconceito de classe e racismo, porém, por serem negras, os avanços em suas lutas eram mais devagar do que as das brancas.

Outras três mulheres de grande importância para o feminismo negro são bell hooks, Angela Davis e Alice Walker. hooks foi uma ativista, teórica feminista, crítica social e escritora a favor dos direitos das mulheres negras; ela nasceu em uma cidade segregada e transmitiu toda sua luta em mais de 30 livros. Ela lutava por uma igualdade em relação aos direitos das mulheres negras em combater o patriarcado igual às mulheres brancas tinham.

Davis lutava por direitos contra a violência sexual e física; e por direitos em relação à classe social e a raça, já que acreditava que a escravidão foi um fator primordial para as mulheres negras serem tratadas de forma mais inferior do que as mulheres brancas, e também por nascer em um local que era gravemente atingido com atentados racistas e muito segregado.

Walker lutava por uma igualdade racial, social e de gênero entre as pessoas, sejam homens ou mulheres, por isso, ela acreditava que o feminismo era um tipo de mulherismo (womanism) fraco, uma ramificação do mulherismo dominado por mulheres brancas que desconsideravam o racismo e o preconceito social, e algumas vezes até contribuía para que essa discriminação acontecesse. Então, ela adotou, disseminou e aplicou esse termo para se referir a mulheres, principalmente negras, que não aceitam as normas padrões que foram estabelecidas por homens e mulheres brancas; que amam uma as outras e se colocam no lugar da outra; e que respeitam todas as culturas e religiões.

Dentro de tantas ramificações do movimento feminista há o feminismo radical, também chamadas de radfem, que enxerga a luta das mulheres como um ato revolucionário, e elas acreditam que todos os direitos que as mulheres já adquiriram ainda são poucos porque a mulher ainda é oprimida e explorada. Elas lutam pelo fim do patriarcado, fim do casamento, legalização do aborto, revisão gramatical da 
linguagem pela língua ainda ser machista e voltada ao homem. Algumas seguem a visão de que as mulheres devem desistir totalmente de relacionamentos amorosos e sexuais com homens.

Contudo, há também uma ramificação do radfem, chamada de feminismo radical transexcludente, conhecida como terf. Elas lutam, além do que foi citado no parágrafo anterior, pela não inclusão de mulheres trans no feminismo, pois acreditam que como não nasceram com o sexo biológico feminino, as trans não entendem como é realmente ser mulher.

O feminismo marxista é voltado para a luta das mulheres em defesa de um espaço de trabalho e leis trabalhistas igualitárias às mulheres, exatamente como as sufragistas na primeira onda. Elas também acreditam que o trabalho doméstico não remunerado exercido pelas mulheres deveria acabar. As feministas marxistas se baseiam em teorias de Karl Marx que falava sobre o capitalismo oprimir as mulheres tratando-as como submissas, escravas e uma mera ferramenta de reprodução; sobre como o trabalho exercido por homens e mulheres são necessários para uma melhor economia; e sobre como a luta de classe é importante e como as mulheres estão incluídas nela.

De acordo com Alves (1991), “[...] o feminismo procurou, em sua prática enquanto movimento, superar as formas de organização tradicionais permeadas pela assimetria e pelo autoritarismo [...]". O movimento feminista luta pela liberdade de direito de escolha, ou seja, a mulher pode querer abortar ou não, casar ou não, ter filhos ou não, trabalhar ou não, entre outras tantas coisas já abordadas neste capítulo.

O feminismo luta não só em prol de conscientizar mulheres, mas, conscientizar homens também, para que eles entendam as causas e possam ajudar a desconstruir o patriarcado imposto historicamente por homens ao defender as lutas feministas, ao se corrigir e corrigir a pessoa que faça algo machista, ao não objetificar mulheres, entre outras coisas. Ressalvo que alguns movimentos feministas não acreditam que o homem possa ajudar e lutar pela causa. Todavia, essa não é a problemática deste capítulo ou deste trabalho. Desta forma, entendo que o homem se conscientizando já estaria realizando uma ajuda indireta ao movimento.

O que não pode acontecer é obrigar a mulher a fazer o que ela não quer, tirar o poder de decisão dela, sendo você homem ou mulher. Pois, enquanto houver uma 
mulher que diga que não precisa do movimento feminista, é porque ela ainda não conseguiu entender as causas e lutas do grupo, então, por isso, o feminismo precisa existir na atualidade.

Nem todos os conceitos, ondas e tipos de feminismo apresentados neste capítulo serão utilizados para o objetivo principal deste trabalho. Entretanto, quis, neste capítulo, fazer um breve resumo tentando abordar vários conceitos, ondas e tipos de feminismo para acrescentar mais informações sobre o assunto feminismo, e assim, ampliar o conhecimento dos leitores. 


\section{Atitudes Feministas}

Este capítulo discorrerá sobre atitudes das personagens femininas Claire Randall Fraser, Jenny Fraser Murray, Geillis Duncan, entre outras, que permitem uma leitura feminista de seus atos na obra literária Outlander: a viajante do tempo. Bem como, explicitar atitudes machistas e consideradas mais adequadas a uma mulher pela visão do patriarcado.

O capítulo em questão será dividido em seis subcapítulos abordando um tema em específico cada um. Os temas são: sexualidade, casamento, maternidade, profissão, violência e patriarcado. Neles serão abordadas as cenas com atitudes de possível leitura com relação ao tema e mostrará ao público-leitor que seja no século $X V I I I$, no século $X X$ ou no século $X X I$ que as mulheres ainda sofrem com praticamente as mesmas questões em relação a sua vida, seu corpo, seu comportamento, suas decisões, entre outros.

Apesar que as mulheres lutaram e conquistaram uma certa liberdade a partir dos muitos direitos alcançados, na atualidade ainda há aqueles que são conservadores, tradicionais e com pensamentos obsoletos que querem que a visão patriarcal continue a dominar a sociedade. Entretanto, como mostra a narrativa, as mulheres, mesmo em 1743, já mostravam certas atitudes contemporâneas e foi desde essas pequenas ações que a luta do movimento feminista começou e perpetua até 2020, fazendo com que mais mulheres conheçam seus direitos e lutem por eles para que nunca mais voltem a ser oprimidas como nos séculos passados.

Essa é uma luta constante que deve ser passada das mulheres para os demais, sejam homens, crianças e idosos. Para que assim, a cultura, os costumes e a política possam mudar, e atitudes machistas, sexistas e patriarcais possam acabar, e futuramente as mulheres possam viver em uma sociedade mais igualitária e com mais oportunidades.

\subsection{Sexualidade}

As mulheres só começaram a pensar em sexualidade a partir do século $X X$ quando a segunda onda do movimento feminista passou a lutar a favor da sexualidade e identidade da mulher. Essa leitura de que a mulher também teria desejos, vontades e prazeres, só foi possível quando as mulheres começaram a perceber e tiveram coragem de declarar que não eram somente um ser reprodutivo. 
Elas não existem somente para procriarem e gestarem herdeiros, elas são seres sexuais independentes.

Como consequência dessa desmistificação da visão e do papel da mulher como ser reprodutor, as mulheres conquistaram a liberdade de não serem reprimidas, de se masturbarem, e de quererem que seus parceiros sexuais as toquem e deem prazer. Elas passaram a entender, não se envergonhar e a não terem medo do seu próprio corpo. Apesar, de que até hoje no século XXI, a menstruação e a masturbação podem ser temas tabus em algumas famílias mais conservadoras e tradicionais.

Na obra literária Outlander: a viajante do tempo, a personagem feminina Claire Beauchamp, também conhecida como Claire Randall Fraser, nasceu no século XX e chegou a absorver essa luta do feminismo pela desinibição da mulher e sua sexualidade. Uma passagem, em que a personagem está em 1945 e mostra isso evidentemente é:

Frank ergueu as sobrancelhas para mim.

- Você deveria gemer em êxtase, não dar risadinhas — repreendeu-me num sussurro. - Ela vai achar que eu não sou um bom amante.

- Você vai ter que continuar por mais tempo do que isso se espera gemidos empolgados - respondi. - Dois minutos não merecem mais do que uma risadinha.

- Que mulherzinha sem consideração. Eu vim aqui descansar, lembra?

- Preguiçoso. Nunca vai conseguir colocar o próximo ramo familiar em sua árvore genealógica se não mostrar um pouco mais de empenho. (GABALDON, 2018, p. 10)

Quando Claire viaja no tempo para 1743, ela continua a ser desinibida e não tem nem um pouco de vergonha de mencionar não ser mais virgem na frente de homens em um ambiente em que só ela era mulher (GABALDON, 2018, p 229).

Apesar de a circunstância da virgindade já ser notória para as pessoas em questão dentro do local, - porque na situação da fala, Claire estava discutindo sobre seu segundo casamento e naquela época era comum, no sentido religioso ${ }^{44}$,

\footnotetext{
44 "O lugar comum é sólido: para o católico o prazer é culpa e o sexo é pecado. Deve ser praticado com parcimônia, no matrimônio com fins voltados exclusivamente a procriação." (p. 266)

"Sendo assim, o cristianismo se afirmou como religião que valorizou o casamento e a castidade como vias espirituais [...] introduzindo uma possibilidade de escolha: casamento ou castidade perpétua, situação não encontrada, por exemplo, no mundo romano." (p. 268)

"O Concílio de Trento vem reforçar o casamento como sacramento, bem como a superioridade do estado de castidade e virgindade." (p. 271)
}

SCARPIM, Fábio Augusto. Dois Em Uma Carne: Igreja e Sexualidade Na História. História:

Questões \& Debates, Curitiba, volume 62, n.1, p. 265-277, jan./jun. 2015. Disponível em:

<https://revistas.ufpr.br/historia/article/view/38590/26702>. Acesso em: 21 out. 2020. 
consumar o casamento com sexo e só então o casal perderia a virgindade, então todos no ambiente já tinham uma possível leitura de que ela não era mais virgem porque consumou o primeiro casamento - a personagem quebrou um tabu gigantesco para o século XVIII ao falar abertamente sobre não ser mais virgem.

Outra cena ocorrida no século XVIII que Claire mostra sua desinibição em sua sexualidade e consciência do seu próprio prazer, acontece na noite de núpcias da personagem feminina com o personagem principal masculino, James (Jamie) Fraser. Nessa ocasião que está entre as páginas 252 e 256, o casal acaba de consumar o matrimônio e entre diálogos dos dois é possível compreender que Claire ensina posições sexuais a James, que é virgem e acredita que o sexo é feito somente por trás igual aos animais que ele observou. Nessa mesma cena, Claire explica a Jamie que ele não deveria acabar rápido com o sexo como ele ouviu de outros homens porque algumas mulheres gostam de sexo e quanto mais devagar melhor seria para tais mulheres.

Bem como, ela pede para o marido se despir para admirá-lo nu, totalmente consciente que sentiria prazer ao ver o belo biótipo de James como ela mesma pensa na cena. Outro momento de impacto no decorrer desta passagem é Claire, na terceira rodada de sexo entre o casal, explicando a Jamie que ela gritou porque teve um orgasmo e não porque ele teria a machucado. Ela pensa, nessa ocasião, que gostou do papel como instrutora das artes do amor e que antes, nunca pensou nela mesma nessa posição.

\subsection{Casamento}

O casamento na obra Outlander: a viajante do tempo é retratado de três formas: por amor, por obrigação e por negociação. Nenhuma dessas formas de retratar o casamento pela literatura é equívoca, pois, elas refletem como o matrimônio é e/ou já foi tratado ao longo dos anos e por várias partes do mundo.

Ao longo da narrativa é deixado explícito que o casamento de lan e Jenny Murray foi por amor, e também o casamento dos pais do personagem principal James Fraser, visto que os pais de Jamie e Jenny fugiram e se esconderam para se casarem. Já o matrimônio de Colum MacKenzie e Letitia Chisholm foi por negociação meramente por terras e herdeiros, igual ao casamento de Geillis e Arthur Duncan, já que Geillis precisava de alguém para mantê-la financeiramente. 
Além desses exemplos no parágrafo anterior, há momentos com a personagem Claire (Beauchamp) Randall Fraser que representa as três razões para se casar já citados. Nesses momentos sobre matrimônio, Claire tem bastante semelhança com as personagens femininas escrita por Jane Austen em suas obras brevemente citadas no capítulo dois deste trabalho.

É possível identificar que as personagens (Claire e as de Jane Austen) são questionadoras, independentes, determinadas, fortes, e nada passivas e submissas. Como no século XVIII era de senso comum, de acordo com os valores patriarcais, a mulher ter que se casar, pois, essa era a única segurança que ela tinha socialmente, é visível - tanto nas obras de Austen como na de Gabaldon - que suas personagens não são induzidas pelo senso comum e que elas têm suas próprias opiniões do que querem, como querem, e quando querem as coisas.

Representando o casamento por amor na vida de Claire, há os momentos dela em lua de mel na Escócia com o seu primeiro marido Frank Randall. A partir da leitura da obra, é plausível dizer que os dois se casaram porque quiseram e se amavam, e que tinham uma relação de companheirismo e bem harmônica. Sobre a representação do casamento por obrigação, temos o momento na página 225 em que Claire é confrontada com a decisão de Dougal MacKenzie de casar ela com seu sobrinho, James Fraser, porém, ela não quer aceitar essa imposição de ter que se casar com um homem escocês.

Em seguida, na página 227, há um momento que representa o casamento por negociação ao Claire retroceder na sua decisão de não se casar com Jamie:

\footnotetext{
Além disso, vista a sangue-frio, a ideia também tinha certo benefício para mim. Se eu fosse casada com um escocês, provavelmente não seria mais vigiada e guardada. Seria muito mais fácil fugir quando chegasse a hora. $E$ se fosse Jamie - bem, ele gostava de mim, sem dúvida. E conhecia as Terras Altas como a palma de sua mão. Talvez me levasse a Craigh na Dun ou ao menos naquela direção. Sim, provavelmente o casamento era a melhor forma de atingir meu objetivo. (GABALDON, 2018)
}

Há ainda o momento sobre casamento por negociação na página 603 em que Dougal MacKenzie oferece uma proposta de matrimônio à Claire Randall Fraser. Nessa oferta ele garantiria sua segurança ao não deixar Claire viúva e sozinha, e obviamente, em troca, ele herdaria todas as terras e herança dos Fraser que estava no nome de seu sobrinho James; e que automaticamente seria passada para o nome de Claire, já que ela era esposa de Jamie e herdaria tudo de seu futuro 
falecido marido. Claire não aceita a proposta e vai tentar salvar seu marido sequestrado pelos ingleses.

\subsection{Maternidade}

Não somente no século XVIII, porém, até os dias de hoje no século XXI, um dos valores patriarcais mais enraizados na sociedade é que a mulher tem que gerar filhos. Todavia, a pressão ocasionada pelo patriarcado para a mulher engravidar e gerar filhos veio de muitos séculos atrás, pois, os homens queriam herdeiros, queriam crianças do sexo masculino para perpetuarem seus sobrenomes e/ou legados. Acontecia que a mulher ficava muito malvista por não querer engravidar, principalmente, se não tivesse uma criança do sexo biológico masculino.

A mulher não podia nem mesmo se negar a fazer sexo com o marido porque era visto como um não cumprimento do dever dela de gerar quantos filhos o marido quiser. O movimento feminista lutou, a partir da segunda onda, pelo direito da mulher não ser obrigada a fazer sexo com o parceiro, pelo direito da mulher escolher se vai querer gerar ou não uma criança, e também lutou pelo direito das mulheres de terem métodos contraceptivos, o que caracterizou a independência da mulher na escola de reprodução ou não.

Há uma crença de que a mulher só é feliz quando ela é mãe, entretanto, nem sempre é assim. Muitas mulheres não sentem nenhuma vontade de engravidar e ter filhos; outras querem ter filhos, mas não querem engravidar; tem algumas que querem ter filhos, mas não podem gerar; tem as que só querem adotar, entre muitas outras opções e decisões.

Um momento na obra literária Outlander: a viajante do tempo que mostra essa pressão do patriarcado sobre a mulher ter que gerar os filhos para o marido é quando a personagem Claire Randall Fraser está em lua de mel com seu primeiro marido Frank Randall em 1945. Nessa cena, na página 39, Frank rejeita a sugestão da esposa sobre eles adotarem uma criança, dizendo que não ficaria confortável com uma criança que não tivesse seu sangue. 
- Bem... é que existem muitas crianças como ele. Órfãs.

Lançou-me um olhar penetrante e balançou a cabeça.

- Não, Claire. Realmente, eu gostaria, mas já lhe disse como eu me sinto a respeito da adoção. É que... eu não iria ficar confortável com uma criança que não fosse... bem, do meu próprio sangue. Sei que isso é ridículo e egoísta da minha parte, mas é assim que eu me sinto. Talvez mude de ideia com o tempo, mas agora... - Andamos alguns passos num silêncio pesado. De repente, ele parou e se virou para mim, tomando minhas mãos.

- Claire - disse com voz rouca - , eu quero o nosso filho. Você é a coisa mais importante do mundo para mim. Quero que seja feliz, acima de tudo, mas quero... bem, quero você para mim. Receio que uma criança de fora, com quem não temos nenhum relacionamento verdadeiro, venha a ser um intruso e eu me ressentiria disso. Mas poder lhe dar um filho, vê-lo crescer em você, vê-lo nascer... eu o veria como se fosse mais uma... extensão de você, talvez. E de mim. Uma parte verdadeira da família. - Seus olhos estavam arregalados, suplicantes. (GABALDON, 2018)

Os métodos anticoncepcionais foram com certeza uma vitória do feminismo no quesito da mulher ter o poder do controle de reprodução, entretanto, ainda há muito pelo que lutar. Um exemplo já citado no capítulo dois, é sobre cirurgias de ligação de trompas em que a mulher tem que ter a assinatura do marido concordando com a cirurgia.

Os homens ainda têm o controle de reprodução das mulheres em mãos, e umas das causas mais polêmicas sobre isso é o aborto, considerado religiosamente como homicídio; e pelo âmbito das leis constitucionais, o aborto pode ser realizado dependendo do contexto como estupro e feto com anencefalia. Todavia, um dos argumentos do movimento feminista em favor do aborto é que mesmo ilegal, as mulheres continuam realizando abortos e muitas morrem nesse procedimento clandestino, essa atitude vem de séculos atrás e continua repercutindo em todo mundo. Então, as feministas lutam pelo procedimento ser legal como questão de saúde pública para as mulheres terem toda uma segurança física e psicológica nesse momento.

Na narrativa escrita por Gabaldon, na página 465, uma personagem chamada Janet Robinson, no século XVIII, é levada diante a um tribunal por seu pai para confessar que engravidou de um homem casado e foi até a personagem Geillis Duncan, que era uma curandeira, para realizar o procedimento de aborto.

Já na página 147, na época de 1743, Geillis Duncan conversa com Claire Randall Fraser sobre uma flor azul pequena que faz a menstruação descer antecipadamente, e assim serve de método abortivo, porém, essa flor só poderia ser usada no começo da gestação porque se fosse usada mais tarde, poderia matar a gestante também. Geillis nessa conversa também confessa a Claire que as moças 
da aldeia tanto solteiras quanto casadas a procuram para fazer procedimentos abortivos.

Essas cenas, tanto em 1945 quanto em 1743, sobre adoção e aborto na obra literária reflete ocasiões ocorridas na vida real dentro de uma sociedade, elas acontecem até a atualidade e nos mostra como o movimento feministas ainda tem muito pelo que lutar em favor da mulher, e também da desconstrução do homem para que ele não repita ações arcaicas e patriarcais, e para que entenda que a mulher tem o direito de escolher, opinar e decidir sobre o que acontece com o seu corpo.

\subsection{Profissão}

Sobre o tema profissão, já foi mencionado no capítulo dois, que as mulheres só conseguiram obter seus direitos trabalhistas legalmente no século XIX durante a primeira onda do movimento feminista depois que o movimento sufragista ganhou força e visibilidade. Entretanto, nem todas as profissões eram vistas como um emprego em que a mulher poderia trabalhar.

Alguns exemplos bastantes característicos sobre o preconceito contra a mulher em determinadas profissões são as cenas citadas a seguir sobre a personagem Claire Randall Fraser sendo desacreditada e não levada a sério, enquanto ela estava em ofício de enfermeira/médica no ano de 1743 na narrativa Outlander: a viajante do tempo.

O primeiro exemplo é nas páginas 75 e 76, nessa passagem, Claire tenta aconselhar seu paciente a não beber tanta bebida alcoólica porque está ferido e não conseguirá se levantar, então, ela é afastada do paciente e chamada de bruxa só porque ela era mulher e tinha conhecimentos médicos. Logo em seguida, Claire tenta fazer com que seu paciente James Fraser, não faça movimentos bruscos para não machucar ainda mais seu ombro, porém, suas queixas são ignoradas.

O segundo exemplo é na página 722, e nessa cena, Claire confronta James ao afirmar que ele não vai poder levantar ainda e nem comer nada sólido no momento, pois, está muito debilitado e já tinha até vomitado naquele dia mais cedo. Ela tenta impor seu conselho ao afirmar ser médica e ele paciente, e que ele deve ouvir o que ela está dizendo, porém, James se levanta e discute com Claire. 
Contudo, também há alguns momentos raros em que Claire é acreditada e levada a sério enquanto estava em ofício de enfermeira/médica. Um exemplo pode ser lido nas páginas 62 e 63 quando Claire se declara enfermeira/médica para Dougal MacKenzie e os homens que o seguiam, após ir em direção ao paciente (James Fraser) com o braço e ombros machucados para ajustá-los. Apesar dos homens no recinto não gostarem da atitude de Claire de tomar a frente da situação, eles acreditaram que ela podia ajudar o amigo debilitado e a deixaram fazer seu trabalho:

- Não se atreva a fazer isso! - Qualquer pensamento de fuga desapareceu diante da indignação profissional. Lancei-me para a frente, sem me importar com os olhares espantados dos homens à minha volta.

- O que quer dizer? - retorquiu o careca, claramente irritado com a minha intromissão.

- Quero dizer que vai quebrar o braço dele se fizer desse modo retruquei. - Saiam do caminho, por favor.

$[\ldots]$

- Ficará dolorido por algum tempo. Não deve de jeito nenhum estender a junta nos próximos dois ou três dias; quando voltar a usar o braço, comece bem devagar. Pare imediatamente se começar a doer e use compressas quentes diariamente.

Percebi, no meio dessas recomendações, que enquanto o paciente ouvia respeitosamente, os outros homens olhavam-me com expressões que iam da absoluta admiração à óbvia suspeita.

- Sou enfermeira - expliquei, ficando um pouco na defensiva.

Os olhos de Dougal, assim como os de Rupert, recaíram sobre meu colo e lá permaneceram com uma espécie de horrorizado fascínio. Trocaram olhares, depois Dougal olhou de novo para o meu rosto. (GABALDON, 2018)

Há também momentos na narrativa em que Claire e a Sra. FitzGibbons estão explicitando seus conhecimentos profissionais, demonstrando para os leitores que as mulheres são inteligentes e capazes de serem ótimas profissionais e que não há razão para o patriarcado duvidar de suas habilidades. Na página 79 , Claire aparece lembrando que a planta alho e a árvore hamamélis são utilizadas para evitar que as pessoas tenham infecções em uma época em que os antibióticos ainda não foram criados. Também há na página 108, uma passagem em que a Sra. Fitz ensina Claire a como fazer um tratamento utilizando sanguessugas:

- Ainda está sangrando sob a pele. As sanguessugas vão ser úteis. Levantou a tampa da tigela, revelando várias lesmas escuras e pequenas, de três a cinco centímetros, cobertas com um líquido de aspecto asqueroso. Com a mão em concha, retirou duas delas e aplicou uma na pele logo abaixo do osso da sobrancelha e a outra abaixo do olho.

- Veja bem - explicou-me -, quando uma contusão se estabelece, as sanguessugas não adiantam mais. Mas quando se tem um inchaço como esse, que ainda está se formando, significa que o sangue está fluindo sob a pele e as sanguessugas podem extraí-lo.

$[\ldots]$ 
- Muita gente não sabe usar sanguessugas - informou-me. - Às vezes são muito úteis, mas é preciso saber usá-las. Quando usadas numa contusão antiga, só retiram o sangue saudável, e isso não adianta nada para o hematoma. Além disso, é preciso ter cuidado para não usar muitas de uma vez; elas enfraquecem uma pessoa que está muito doente ou que já perdeu muito sangue.

Ouvi respeitosamente, absorvendo todas as informações, embora eu sinceramente esperasse que nunca me pedissem para usar aquilo.

- Agora, rapaz, faça um bochecho com isso; vai limpar os cortes e aliviar a dor. Chá de casca de salgueiro - explicou-me - , com uma pitada de raiz de íris moída. - Assenti; lembrava-me vagamente de ter ouvido em uma antiga aula de botânica que a casca do salgueiro continha ácido salicílico, o ingrediente ativo da aspirina.

- A casca de salgueiro não aumenta a possibilidade de sangramento? perguntei.

A sra. Fitz confirmou:

— Sim. Às vezes, sim. É por isso que, em seguida, você dá um punhado de erva-de-são joão embebida em vinagre; isso estanca o sangramento, se tiver sido colhida na lua cheia e bem moída. (GABALDON, 2018)

\subsection{Violência}

A violência é uma questão bem marcante no livro Outlander: a viajante do tempo com cenas bastantes explícitas sobre violência física e psicológica. Elas acontecem com as personagens femininas Vovó McNab, Jenny Murray Fraser e Claire Randall Fraser, e refletem não só preocupações e medos que as mulheres tinham no século XVIII, mas também, o que mulheres no século $X X I$ ainda receiam e/ou sofrem.

Um exemplo sobre violência física contra a mulher é quando Vovó McNab, na página 537, confessa a Claire que já apanhou do marido. Quando o marido bateu nela pela primeira vez, ela em reação pegou o ferro da lareira e acertou na cabeça dele. Ela ficou desesperada porque pensou que matou ele, porém, ele se recuperou e nunca mais tentou bater nela nem nos filhos. No exemplo anterior é possível a leitura de que a reação de Vovó McNab em bater de volta fez com que o marido tivesse medo e não voltasse a tentar bater nela nunca mais. Entretanto, nem toda mulher tem uma reação ou sua reação sucede em algum resultado; e nem sempre o agressor vai parar de bater.

Segundo Beauvoir (2009), a mulher é considerada uma propriedade do homem, primeiro de seu pai que a vende e segundo, do marido que a compra. Por isso, as mulheres não tinham direitos de herdar heranças, era porque elas eram vistas somente sobre uma perspectiva patriarcal como se fossem um mero produto a venda. Seguindo a lógica do patriarcado, já que a mulher é uma propriedade com 
dono, então o dono pode fazer o quiser com ela, isso inclui bater, estuprar, matar, castigar, vender, entre outros.

Eram esses pensamentos e uma sociedade dominada por homens que faz, até nos dias atuais, o homem pensar que tem posse de uma mulher mesmo a mulher já sendo considerada e detentora de direitos exclusivos a ela para assegurálas de estudo, trabalho, herança, próprio dinheiro, bem-estar, ir e vir, casar ou não, ter filhos ou não, entre outros.

Exemplificando com a obra sobre esse pensamento de posse temos cenas, nas páginas 345 a 347, no parágrafo a seguir, que mostram, evidentemente, que James Fraser pensa que tem e pode que punir Claire Randall Fraser para fazer com que ela siga suas ordens porque ela é sua esposa, subentendidamente sua propriedade, uma situação corriqueira e comum no século XVIII.

A cena começa com uma discussão do casal Claire e James Fraser, então, James diz que vai ter que punir Claire pela desobediência dela e que mesmo pedindo desculpas, e ela entendendo mentalmente o erro, ela só vai internalizar o erro quando apanhar. E também complementa dizendo que Claire apanhando será como justiça para com ele e com os outros homens do bando que foram atacados devido ao erro dela. Ele termina seu discurso dizendo que como marido dela é dever dele ensiná-la.

Obviamente, como uma mulher independente e nada submissa, Claire tenta lutar contra James. Ela diz que não permite que ele bata nela e se agarra ao dossel da cama, ele rebate dizendo que como marido ele poderia bater nela, quebrar seu braço, trancá-la em um quarto e deixá-la só se alimentando com pão e água. Ela diz que vai gritar e ele debocha dela dizendo que ela tem bons pulmões e que poderia gritar bem alto. James solta os dedos de Claire agarrados no dossel e a arrasta para a beira da cama, então, como autopreservação, ela chuta a canela dele, porém, não adianta de nada, pois ele consegue colocá-la de bruços, pegar o cinto e começar a bater nela. Claire continuou lutando, todavia, não conseguiu se soltar:

Fora uma noite extremamente desagradável. Minha relutante aquiescência durará precisamente até o primeiro estalo abrasador do couro na pele. A isso seguiu-se uma luta curta e violenta, que deixou Jamie com o nariz sangrando, três belos arranhões em um dos lados do rosto e um pulso com uma mordida profunda. Como era de se esperar, isso me deixou esmagada contra as cobertas encardidas, com um joelho nas costas, surrada quase até a morte. (GABALDON, 2018) 
Uma das formas de violência física não é somente agressão, mas também, o assédio sexual e estupro. Um exemplo de assédio sexual que acontece na narrativa, na página 84 , é quando James fala para Claire que sua irmã, Jenny, tinha sido assediada por Jonathan Randall, vulgo Black Jack, uns anos antes quando os soldados ingleses comandados por Randall invadiram as terras dos Fraser.

Jamie conta que Black Jack dobrou o braço de Jenny atrás das costas e depois passou a mão nos seios dela enquanto sorria, porém, ele não esperava que a menina lutasse. Jenny pisa no pé de Randall e enfia o cotovelo na barriga dele, fazendo ele ficar sem ar, e em seguida, dá uma joelhada nas partes íntimas. Infelizmente, Jack se recupera e faz Jenny de refém de novo.

Outro exemplo de assédio é quando Claire se encontra com Black Jack pela primeira vez (página 54). Ele a agarra na floresta e em meio aos protestos dela de se desvincular dele, Randall a beija de língua. Ela enfim se recupera do choque e grita bem alto diretamente no ouvido dele fazendo com que leve um susto e se afaste. Então Claire aproveita a oportunidade, dá uma joelhada nele e tenta correr. Nesta cena, felizmente a personagem consegue ter uma reação, porém, não foi imediata; e isso acontece muito na vida real.

Ao longo da obra há vários exemplos de tentativas de estupro, principalmente, com a personagem Claire Randall Fraser e neste subcapítulo será apresentado dois. O primeiro com Jenny Fraser Murray quando Black Jack invade as terras do Fraser e o segundo com Claire Fraser quando é emboscada por soldados ingleses. Ambas lutam fervorosamente por suas vidas e acabam, felizmente, desviando dessa fatídica situação.

$\mathrm{Na}$ página 547, Jenny conversa com seu irmão James e conta o que verdadeiramente aconteceu com ela e Randall no dia da invasão à Lallybroch, terra dos Fraser. Jenny diz que levou Black Jack para o quarto dela dentro da casa e então percebeu ele bem nervoso ao empurrá-la na cama e se esfregar nela, mas ela percebeu que ele não conseguia ficar excitado e começou a rir dele. Mesmo sob extrema pressão e medo, Jenny utilizou do riso como tática para fazer Randall perder o controle e não conseguir estuprá-la.

- Ele não gostou quando eu ri, e pude notar, de modo que ri ainda mais. Foi quando ele se atirou em cima de mim e rasgou meu vestido. Dei-lhe uma bofetada e ele me deu um soco no queixo, suficientemente forte para me fazer ver estrelas. Em seguida, gemeu um pouco, como se isso the desse prazer, e começou a subir na cama ao meu lado. Estava quase desmaiada, mas ri outra vez. Com dificuldade, fiquei em pé e eu... eu o 
ridicularizei e insultei. Disse que sabia que ele não era homem de verdade e não conseguia lidar com uma mulher. Eu...

[...]

- Bem, foi o que fiz - disse ela. - Foi tudo em que consegui pensar e pude ver que ele ficou fora de si, mas também era claro que ele... não conseguia. Olhei direto para suas calças e ri de novo. Então, ele me agarrou pelo pescoço, me estrangulando, e eu bati com a cabeça na coluna do dossel da cama e... e quando acordei, ele havia ido embora, e você com ele. (GABALDON, 2018, p. 248)

Já na cena com Claire Fraser na página 319, o que acontece é que Claire e seu marido James estavam em um momento íntimo perto de um lago quando dois soldados ingleses desertores os avistam e tentam estuprar Claire. Entretanto, a personagem percebe que está com uma adaga no bolso da saia e pensa em atacar o soldado que está em cima dela. Ela passa o braço pelo pescoço dele, o prende pelas pernas e o esfaqueia na costela.

Também há uma cena de tentativa de estupro marital ${ }^{45}$ relacionado ao casal James e Claire Fraser. Estupro Marital é quando o marido argumenta e/ou age como se a esposa tivesse que fazer sexo com ele porque é o dever dela, ou seja, a mulher é vista como propriedade do homem e dentro do casamento ela tem a obrigação, gostando ou não e querendo ou não, de se relacionar sexualmente com ele como um dever contratual que está ligado ao matrimônio dos dois. Essa é uma visão histórica, cultural, patriarcal e sexista muito comum até os dias de hoje, porém, muito mais forte no século XVIII onde se passa a obra.

Um exemplo pode ser visto na página 367 quando James Fraser diz claramente que Claire Randall Fraser tinha que Ihe dar créditos por ele praticar a paciência e compreensão em dormir no chão e não fazer sexo com ela após bater nela porque ele não achou certo. Ela o responde dizendo que se ele tivesse tentado, iria perder as partes íntimas e que ele não merecia elogios por se conter a não estuprar a esposa em seguida de uma agressão.

Outro exemplo é visto na página 379 quando Claire diz que não quer ter relações sexuais com o marido James, porém, ele ainda tenta forçá-la e argumenta que no contrato de casamento diz que ela deveria obedecê-lo, e isso, incluía os deveres dela copular com ele quando ele quisesse. Entretanto, ela discute com o marido dizendo que ele não tinha esse direito de obrigá-la a ter sexo e que se

\footnotetext{
${ }^{45}$ VIANA, Rannyela. Estupro Marital frente aos deveres conjugais. Jusbrasil. Disponível em: $<$ https://rannyelaviana.jusbrasil.com.br/artigos/416933770/estupro-marital-frente-aos-deveresconjugais?ref=feed $>$. Acesso em: 3 nov. 2020.
} 
tentasse forçá-la, ele se compararia à Black Jack que já tinha assediando-a e tentado estuprá-la. A cena foi descrita neste modo:
— Eu não quero dormir com você! — falei, quando finalmente libertou minha boca.
- Não pretendo dormir, Sassenach - retorquiu ele sem se alterar. - Ainda não. - Alcançou a cama e colocou-me cuidadosamente na colcha decorada com desenhos de rosas.
- Sabe muito bem o que quero dizer! - Rolei na cama, pretendendo escapar pelo outro lado, mas fui interrompida por um aperto firme no meu ombro que me virou de frente para ele. - Também não quero fazer amor com você!
Os olhos azuis lançavam faíscas à queima-roupa e minha respiração ficou presa na garganta. - Não perguntei sua opinião sobre o assunto, Sassenach - respondeu ele, a voz perigosamente baixa. - Você é minha mulher, como já lhe disse várias vezes. Se não queria se casar comigo, assim mesmo escolheu se casar. E se não notou na ocasião, sua parte do protocolo incluía a palavra "obedecer". Você é minha mulher e se eu a quiser, mulher, eu a possuirei e dane-se! - Sua voz foi se elevando enquanto falava, até estar quase gritando.
Ergui-me nos joelhos, os punhos cerrados junto aos lados do corpo e gritei em resposta. A angústia contida da última hora atingirá o ponto de explosão e não me contive, sem maiores considerações.
- Eu é que quero que se dane se vou deixar que me tenha, seu porco nojento! Acha que pode me obrigar a ir para a cama com você? Usar-me como uma prostituta quando tiver vontade? Bem, não pode, seu filho da mãe desgraçado! Foda-se! Faça isso e vai se igualar ao seu capitão Randall! (GABALDON, 2018)

Além de haver muitas cenas de violência física, também houve cena de violência psicológica na narrativa literária de Outlander: a viajante do tempo. A cena gira em torno da culpabilização da vítima, James tenta fazer Claire se sentir culpada por quase ter sido vítima de um estupro e não admite que está com o orgulho ferido pela esposa ter salvo a vida dos dois em uma outra ocasião.

Essa cena foi longa durando da página 339 a 341 e está ligada ao casal James e Claire Fraser. Nela, James culpa Claire por quase ter sido estuprada dizendo que ela não o obedeceu ficando no local em que combinaram e por esta razão a situação aconteceu. Já Claire diz que a culpa pelo ocorrido é dele por ignorá-la e não deixá-la ir com ele, ela o acusa dele nunca ouvi-la porque é mulher, e também diz que o que James espera é uma mulher dócil, submissa, que segue ordens e espera que o homem a diga o que fazer. James retruca que se ela tivesse feito isso, então, eles não teriam que fugir no momento de soldados ingleses.

Ela em seguida tenta dar uma joelhada nas partes íntimas dele quando ele fala que tinha vontade de bater nela. Ele ameaça bater nela se ela tentar chutá-lo de novo. Então, muito irritada, Claire pergunta a James se ela foi capturada de propósito e ele afirma que ela fez de vingança por outro ocorrido. 
Logo, ela o acusa de enxergá-la somente como uma propriedade e não sua esposa, e como uma criança birrenta que não gosta quando outras pessoas pegam suas coisas. Ele responde que ela o pertence, e consequentemente ela grita dizendo que ele não se importa com ela, e sim com o fato de ter uma esposa para ter relações sexuais, e diz que ele não manda nela. A cena se encerra com Claire o acusando de estar com o orgulho ferido por ela ter salvado a vida dos dois ao matar o soldado inglês que tentou estuprá-la em outra ocasião e que ele não pode fazer nada.

Infelizmente, no século XVIII não existiam leis que protegessem as mulheres de passarem por situações horríveis e traumatizantes como as descritas anteriormente, elas só puderam contar com elas mesmas e sua própria força de vontade e coragem para sobreviverem e se reerguerem. Nenhuma delas pode ter um tempo ou ajuda para se recuperarem da fatídica situação, elas tinham que se virar para seguirem em frente porque era uma situação comum e banal naquela época. Felizmente, no século XXI temos leis de proteção as mulheres, instituições sociais e ONGs que tornam esses casos menos banais e mais visíveis, entretanto, ainda são muito comuns como a teórica Marli Gonçalves (2019) divulga em seu livro.

\subsection{Patriarcado e/ou Comportamentos fora do padrão}

O patriarcado está presente na maioria dos países, culturas, políticas, sociedades e religiões ao longo dos séculos, e o movimento feminista vem lutando desde o século XVIII para garantir que as mulheres consigam seus direitos conforme a cultura, época e país em que elas habitam, para assim, garantir que todas tenham visibilidade, reconhecimento, independência e voz.

A visão patriarcal passou séculos oprimindo mulheres fazendo-as submissas, sendo silenciadas e punidas, obrigadas a uma vida toda dominada pelas decisões dos homens, sendo diminuídas a somente uma reprodutora, consideradas loucas e bruxas por não concordarem a uma vida de subjugação e servidão, entre outros. Apesar do progresso em relação a leis, direitos e a liberdade que as mulheres conquistaram, ainda há um contraste enorme e muito óbvio em comparação aos homens que está disfarçando o preconceito.

Há exemplos de patriarcado na narrativa de Outlander: a viajante do tempo, um deles se passa no século XVIII (página 522) e mostra que a personagem Jenny 
Murray aos 10 anos teve que se tornar a administradora da casa quando sua mãe morreu porque era a única pessoa do sexo feminino da família viva, mesmo tendo pai e irmão mais velho para exercer a função.

Também há o exemplo ocorrido no século XX que mostra a personagem Claire Randall Fraser sendo pressionada a se encaixar em um comportamento considerado o adequado: "Eu me mostrara recatada, bem-educada, inteligente, mas modesta, elegante e discretamente vestida - tudo que a mulher perfeita do professor universitário deveria ser. Até o chá ser servido." (GABALDON, 2018, p. 20), porém, não era o seu natural. Tanto que a personagem tem afeição e se aproxima de Geillis Duncan porque, de acordo com seus pensamentos, Duncan não botava uma máscara de mulher perfeita, principalmente para o ano em que as duas estavam, que era 1743.

[...] Gostei imensamente da companhia de Geillis; ela possuía uma visão irônica, cínica, que era um revigorante contraste com as mulheres meigas e tímidas do castelo. E, obviamente, ela era bem-educada para uma mulher numa pequena vila. (GABALDON, 2018, p. 151)

Outro exemplo de opressão sobre o comportamento feminino são os palavrões. A personagem Claire utiliza de muitos xingamentos, pois é algo natural para ela, sobretudo, após ser enfermeira na Segunda Guerra Mundial. Uma das ocasiões em que ela xingou foi em 1945, na página 20, quando sem querer deixou cair o bule quente em cima do Sr. Bainbridge e exclamou um "Puta que pariu!" devido ao susto do acidente e seu marido Frank Randall a olha enfurecidamente devido ao palavrão dito.

Em outra ocasião (página 94), Claire profere a palavra diabos em uma discussão com Colum MacKenzie, senhor do castelo Leoch, e ele pisca totalmente desconcertado e intrigado com as palavras pronunciadas por ela. Ou quando em 1743, Claire foi repreendida pelo bando de Dougal MacKenzie por ela usar palavrões enquanto cuidava dos ferimentos de James Fraser, entretanto, naquela circunstância, ela rebate os homens dizendo para que eles não se metam na vida dela.

— Volte aqui, seu... ah, seu desgraçado maldito filho da mãe! - Jamie mexera-se e a ponta que já estava amarrada se soltou.

Fez-se um momento de silêncio chocado.

- Nossa! - exclamou o gordo de nome Rupert. - Nunca ouvi uma mulher usar essa linguagem em toda a minha vida. 
— Então você não conheceu minha tia Grisel — disse outra voz, seguida de uma risada geral.

- Seu marido devia lhe ensinar, dona - retorquiu uma voz austera saída da escuridão atrás de uma árvore. — São Paulo disse: "Que uma mulher fique em silêncio e..."

- Meta-se com sua vida - falei entre dentes, o suor escorrendo por trás de minhas orelhas - e São Paulo também. [...] (GABALDON, 2018, p. 74)

Na cena da página 309 descrita a seguir, Claire pede ao seu marido James para ensiná-la a usar uma arma, porém, ele nega respondendo que ela é mulher e por essa razão não vai ensiná-la a carregar e disparar a pistola. Ela rebate, muito irritada, perguntando se ele pensa que mulheres não são capazes de compreender como se opera uma arma. Então, Rupert a explica que por ela ser pequena e magra, e a arma dar um coice muito forte para trás, Claire pode se machucar ao atirar; ele até exemplifica dizendo que tem vários machucados devido ao coice.

Nessa cena podemos ver a visão patriarcal inserida em James Fraser no momento em que ele não se dá nem ao trabalho de explicar a sua esposa o motivo do porquê dele não ensiná-la a usar a pistola. Pode parecer uma cena marcada pela época machista e conservadora (século XVIII), porém, até na atualidade (século XXI) existem homens que pensam que as mulheres são inferiores, não capazes e nem inteligentes o suficiente, logo ignoram o sexo feminino como se fosse insignificante até para uma resposta.

Uma personagem feminina que foge desse estigma de como uma mulher deve ser e se comportar é Ellen MacKenzie Fraser, mãe de James e Jenny Fraser, e entre as páginas 415 e 419, Claire Randall Fraser e Alec MacMahon conversam sobre ela. Na conversa é citado que Ellen era uma mulher que dava sua opinião sem medir palavras e sem se importar com o que dissessem, era desbocada, geniosa e nada dócil. Tanto que, quando pressionada a casar-se por uma boa aliança para o clã MacKenzie, Ellen fugiu com o rapaz que gostava para se casar fazendo com que todos da sua família a procurassem.

Entretanto, foi bem difícil achá-la e também demorou bastante, contudo, foi de acordo com o plano de Ellen. Ela e o rapaz, que se chamava Brian Fraser, pretendiam se esconder até ela ficar grávida e a família não poder negar mais o casamento dos dois, e assim foi que aconteceu. Quando o clã MacKenzie encontrou Ellen, ela já estava grávida do primeiro filho do casal. A personagem se mostra independente e bem decidida do que quer, muito divergente do que era imposto às mulheres da época. 
Ainda no clã Fraser, porém, falando sobre Janet (Jenny) Fraser Murray, há uma cena que vai da página 510 a 512 que mostra ela discutindo com o irmão James e que indica que Janet não tem características de uma mulher submissa, delicada e nem obediente. O início da cena pode ser visto nessa passagem:

— Não! Não fale comigo! Já disse que não vou aguentar ouvir!

- Ah, é mesmo? - Jenny observou seu irmão, parado à janela, com as pernas afastadas, as mãos no peitoril e as costas teimosamente voltadas para ela. Ela mordeu o lábio e uma expressão calculada surgiu em seu rosto. Rápida como um raio, ela se inclinou e enfiou a mão embaixo do seu kilt como o bote de uma cobra.

Jamie soltou um rugido de pura indignação e se empertigou de choque. Tentou virar-se, depois parou, imóvel, quando ela aparentemente redobrou o aperto.

- Existem homens razoáveis - disse ela para mim, com um sorriso malicioso - e animais que podem ser subjugados e obrigados a obedecer. Com outros não se pode fazer nada, a não ser que os segure pelo saco. Agora, pode me ouvir de maneira civilizada - disse a seu irmão - ou vou ter que torcer um pouco? Hein?

Ele permaneceu imóvel, o rosto vermelho, respirando ruidosamente através dos dentes cerrados. (GABALDON, 2018)

Logo em seguida, depois de Jenny largar os testículos de James, ele a pergunta o porquê de ela desobedecê-lo na época em que Black Jack Randall invadiu Lallybroch, as terras da família Fraser. Janet fica enfurecida, pronta para brigar e o responde:

- Ah, desobedecer as suas ordens, hein? É isso que o está incomodando, Jamie, não é? Você sabe o que é certo e, se não seguirmos as suas ordens, vamos nos arruinar, sem dúvida.

- Movia-se impacientemente de um lado para outro, furiosa. - E se eu tivesse feito o que você mandou, naquele dia, você teria sido morto no pátio de entrada, papai teria sido enforcado ou estaria na prisão por assassinar Randall e as terras teriam sido confiscadas pela Coroa. Para não dizer nada de mim, sem lar e sem família, precisando mendigar nas vielas para viver. (GABALDON, 2018)

James, ainda com orgulho ferido pela sua irmã ter razão na situação, a ofende chamando-a de inflada como um sapo maluco por estar grávida. Então, Jenny o estapeia fortemente deixando a marca de seus dedos no rosto dele. Ela não o teme nem tem receio pelo que ele possa fazer com ela, Janet age corajosamente em relação à visão patriarcal do século XVIII, pois, nessa ocasião tanto James quanto seu marido lan poderiam puni-la pela bofetada.

Na página 519, Jenny ainda discutindo com James, deixa ele atônito e embaraçado ao se mostrar nada frágil e indefesa quando pergunta o porquê ela não poderia dar sua vida em troca da dele. Ele, por fim, não consegue responder e então, ela continua dizendo que ama ele e que nunca o deixaria morrer se pudesse 
salvá-lo. Assim, ela cumpre com suas palavras na página 583 ao pedir a Claire Fraser que ajude o marido lan a ir para casa com o bebê recém-nascido para elas pegarem os cavalos e irem atrás de James para libertá-lo de ser mandado à forca pelos ingleses.

$\mathrm{Na}$ narrativa Outlander: a viajante do tempo, há também outros momentos que mostram a mulher como heroína, salvadora, nada delicada, fraca e inofensiva. Neles temos as personagens Jenny Murray e Claire Fraser como protagonistas. $O$ primeiro momento é na página 586 quando as ambas emboscaram um soldado inglês para conseguir informações sobre o paradeiro de James Fraser.

Jenny entrou no caminho do soldado, assustando o cavalo dele, enquanto Claire saiu do esconderijo e o atingiu com força na cabeça o derrubando no chão. Totalmente surpreso, o homem não teve reação enquanto Jenny escondia o cavalo dele e Claire o amarrava a uma árvore. Elas o ameaçaram com uma pistola para fazê-lo contar a localização de Jamie, e como estava completamente rendido, ele conta as duas a informação que querem.

O segundo momento é mostrado na página 602, quando já com o paradeiro de seu marido James, Claire vai até onde Dougal MacKenzie e seu bando para conseguir a ajuda deles para salvar seu marido, todavia, eles não querem arriscar suas vidas para salvá-lo. Contudo, na página 608 é mostrado que Claire não desiste e nem se conforma com a decisão de Dougal, então, ela ordena que todos esperem antes de irem embora e a escutem, fazendo com que todos a olhem espantados.

Ela faz um acordo com Dougal para que ele dê permissão para os homens que quiserem salvar James com ela, possam ir sem problemas, já que ele é o líder. Dougal concorda acreditando que ninguém iria ser persuadido por uma mulher, porém, se espanta que alguns homens aceitaram arriscar suas vidas para salvar o amigo e vão com Claire.

O terceiro e último momento, que considero de relevante metáfora da luta das mulheres contra o patriarcado, ocorre entre as páginas 641 a 645, quando Claire luta contra lobos para salvar sua vida, como é explícito na cena a seguir: "Só havia espaço em minha mente para um único pensamento: vou matar este animal ou ele me matará. Portanto, eu iria matá-lo." (GABALDON, 2018, p. 642). Nessas passagens a seguir, ela se mostra corajosa, forte, determinada, focada e resistente, inteiramente de maneira oposta ao que a visão patriarcal tem sobre as mulheres. Essa cena é um exemplo de como as mulheres foram e ainda são subestimadas 
pelo homem, porque Claire após passar por um turbilhão de problemas para encontrar e resgatar o marido, ainda teve que se defender para preservar sua vida. Alguns fragmentos dessa cena são:

\begin{abstract}
Desamarrei os laços na minha garganta e comecei a apalpar o broche que prendia meu manto, ainda dizendo ao lobo, em voz alta e firme, o que pensava dele, de seus ancestrais e de sua família imediata. $O$ animal parecia interessado na ladainha, a língua relaxada e os dentes à mostra, como um cachorro. Não parecia ter pressa; mancava levemente, pude notar quando se aproximou, e era magro e sarnento. Talvez tivesse dificuldade em caçar e a enfermidade é que o atraía à pilha de lixo da prisão para catar comida. Eu certamente esperava que assim fosse; quanto mais doente, melhor.

Encontrei minhas luvas de couro no bolso do meu manto e calcei-as. Em seguida, enrolei o manto várias vezes em torno do braço direito, abençoando a espessura do veludo. (GABALDON, 2018, p. 641)
\end{abstract}

Nesta passagem da luta pela conservação da vida da personagem Claire Randall Fraser é possível termos uma leitura de uma mulher lutando contra o patriarcado, que seria metaforicamente entendido aqui pela figura masculina do lobo. Nesta luta, observo uma metáfora plausível entre presa $x$ predador, ser humano $\mathrm{x}$ animal, mulher $x$ homem e, por fim, numa perspectiva política de luta constante: feminismo x patriarcado. Em resumo, observo através dessa análise que tanto a presa quanto o ser humano, assim como, a mulher e o feminismo lutam pela sobrevivência em um ambiente hostil cheio de predadores, animais, homens perpetuadores do patriarcado.

Nem cheguei a ver o lobo sair do solo. Eu podia jurar que estava vigiando seus olhos, mas se a decisão de saltar tivesse sido registrada ali, fora seguida depressa demais pela ação para que eu pudesse notar. Foi o instinto, e não o pensamento, que ergueu meu braço quando uma mancha cinza-esbranquiçada se arremessou sobre mim.

Os dentes cravaram-se no acolchoamento com uma força que machucou meu braço. Era mais pesado do que eu imaginara; eu não estava preparada para aquele peso e meu braço afrouxou. Planejara atirar a fera contra a parede, talvez deixando-o desacordado. Em vez disso, arremessei o corpo contra a muralha, esmagando o lobo entre os blocos de pedra e meu quadril. Lutei para envolvê-lo com a parte solta do meu manto. (GABALDON, 2018, p. 642)

A personagem Claire chega a comparar a força que ela detém no momento da luta contra o lobo faminto com o fato de que, normalmente, a mulher encontra esse estímulo de supervivência na hora do parto e o homem encontra-o na hora da batalha.

Chega-se a um ponto, numa intensa luta física, em que uma pessoa se abandona ao uso desenfreado de força e recursos corporais, ignorando os custos até a luta acabar. As mulheres encontram este ponto no parto; os homens na batalha. (GABALDON, 2018, p. 642) 
Todavia, Claire como mulher está encontrando, pela primeira vez, esse ímpeto em uma batalha. Deixando claro que uma mulher tem a mesma força que um homem, tanto que é possível entendermos que é essa força que faz as mulheres lutarem contra o patriarcado.

A representação que a passagem a seguir retrata, sugere metaforicamente toda a luta que as mulheres tiveram e ainda têm que enfrentar desde quando o movimento feminista começou a surgir no século XVIII em prol de uma educação acadêmica igualitária a dos homens. Constantemente, as mulheres têm que arrancar um lobo que tenta remover seu braço ou dar uma joelhada nele, pois, todos os dias, há um predador com convicções patriarcais, pronto para atacá-las, desmotivá-las e tentar subjugá-las.

Joguei-me sobre o animal, prendendo-o sob o meu corpo e extraindo todo o
ar de seus pulmões num sopro putrefato. Ele se recuperou quase
imediatamente e começou a se contorcer sob o meu corpo, mas o segundo
relaxamento me permitiu arrancá-lo do meu braço, uma das mãos
grampeada por baixo de seu focinho molhado.
Forçando meus dedos nos cantos de sua boca, consegui mantê-los fora dos
dentes carnívoros e cortantes. A saliva escorria pelo meu braço.
[...]
Rolei bruscamente para fora e o lobo imediatamente escorregou para o
pequeno espaço livre entre meu corpo e a muralha. Antes que pudesse ficar
de pé, atingi-o com o joelho com todas as forças que consegui reunir. O
lobo grunhiu quando meu joelho se chocou contra a lateral do seu corpo,
prendendo-o, ainda que apenas por alguns instantes, contra a parede.
(GABALDON, 2018, p. 643)

Ao refletir sobre essa luta da personagem Claire com o lobo, compreendi que ao redor de toda mulher há um lobo na espreita, entretanto, elas são fortes o suficiente para encarar essa luta e vencer. Todavia, um lobo sempre anda em bando, ou seja, onde há um lobo, haverá uma alcateia pronta para atacar. Contudo, na atualidade as mulheres não lutam sozinhas, elas têm o movimento feminista para apoiá-las e defendê-las. Foi possível assimilar essa reflexão a partir da passagem a seguir:

Não houve nenhum ruído audível, mas eu senti a reverberação pelo corpo todo quando o pescoço dele se quebrou. Os membros tensos - e a bexiga - imediatamente relaxaram. Com o esforço insuportável dos braços agora relaxados, caí, tão fraca quanto o lobo moribundo. Podia sentir o coração da fera fibrilando sob a minha face, a única parte do seu corpo ainda capaz de lutar contra a morte.

[...]

A sorte me ajudara com o primeiro lobo; não havia nem uma chance em mil de que eu pudesse matar outro animal de mãos vazias - e quantos mais deveria haver?

$[\ldots]$ 
O primeiro predador apareceu na borda da vala como seu antecessor; uma figura desgrenhada, imóvel e alerta.

$[\ldots]$

No começo, pensei que um dos meus projeteis tivesse atingido o alvo. 0 lobo mais próximo ganiu e pareceu ter um espasmo. Mas a segunda flecha passou a uns 30 centímetros de mim e vi a minúscula mancha em movimento antes de se alojar com um ruído surdo no peito do segundo lobo. Esse animal morreu ali mesmo onde estava. (GABALDON, 2018, p. 644, 645)

A alcateia, entendida aqui, como o coletivo do patriarcado ainda não foi desmantelada da sociedade, porém, as mulheres não desistiram e quantos mais lobos mostram seus dentes e garras, mais o feminismo se dispõe a combatê-los. Apesar de parecer que o movimento fez pouca coisa nos últimos três séculos, o feminismo só está começando. Ainda há muito pelo que se lutar, entretanto, muito já foi conquistado. O que não pode neste momento é permitir a regressão da posição que as mulheres alcançaram na sociedade, deve-se manter o que foi adquirido e continuar a obter o que as mulheres reivindicam por questões de igualdade. 


\section{CONSIDERAÇÕES FINAIS}

Este trabalho de conclusão de curso é baseado em pesquisa bibliográfica na narrativa literária Outlander: a viajante do tempo. Busquei informar sobre a ficção dita e alguns aspectos que tenham ligação com ela, como: os nomes de todos os livros da série literária, o porquê da viagem no tempo, o motivo da Escócia ser o cenário, a graphic novel, a série televisiva, os personagens da obra e sobre a autora Diana Gabaldon. Em adição ao mencionado posteriormente, discorri sobre teorias, falas, conceitos e correntes feministas para interligar todos os aspectos mencionados anteriormente.

Como o objetivo principal deste projeto é analisar cenas de uma obra literária em que atitudes das personagens femininas são interpretadas como feministas, utilizei da narrativa literária Outlander: a viajante do tempo para ser a ficção em que este trabalho de conclusão de curso é pautado, pois, acredito que há muito material na obra que possa ser observado pela perspectiva das teorias feministas e suas pensadoras que contribuem para luta através de estudos, falas, pensamentos, teorias, filosofias, escritas, entre outros.

Uma das grandes motivações, vinda desse material ficcional da narrativa, para utilizar Outlander: a viajante do tempo como objeto de estudo foi o fato deque as personagens femininas viviam em 1743 , uma época de muito conservadorismo e com o patriarcado bastante enraizado na sociedade mundial, e mesmo assim, muitas mulheres da obra demonstraram ter atitudes, que hoje no século XXI, seriam consideradas parte da luta do movimento feminista.

Mesmo que a personagem Claire tenha vindo de uma época mais moderna (ano de 1945, pós Segunda Guerra Mundial), - já era esperado por parte dos leitores que Claire fosse mais vanguardista do que as mulheres do século XVIII, pois no século $\mathrm{XX}$ as mulheres já podiam trabalhar e votar, respeitando, é lógico a questão cronológica de que as causas ganhas pelas mulheres em 1945 são bem menores do que as de 2020. Então, os leitores do século XXI podem observar o quanto o movimento feminista apoiou e ajudou as mulheres ao longo dos séculos a conquistarem visibilidade e seu espaço na sociedade como um todo.

Por isso, um dos objetivos deste trabalho é desconstruir a noção que muitos homens e, infelizmente, mulheres, que são conservadores e machistas, ainda acham do feminismo. Em razão disso, o projeto abordou sobre as ondas, conceitos e 
ramificações do feminismo existentes ao longo dos séculos durante todo o capítulo 2 intitulado O Feminismo e suas 3 ondas.

De modo a complementar esse objetivo, o capítulo 1 foi escrito para oferecer um breve resumo da narrativa Outlander: a viajante do tempo, apresentando diversas informações sobre todos os livros da série literária Outlander, porém, focando mais no primeiro volume, sobre os spin-offs feitos a partir do sucesso da narrativa e sobre os fatos por trás dos bastidores da escrita das obras. Bem como apresentou informações sobre a vida da autora Diana Gabaldon como formação profissional, vida privada, como ela começou escrever, pesquisas que fez para escrever seus livros, método de escrita, inspirações, entre outros elementos.

O primeiro capítulo também apresentou sobre os personagens mais relevantes para esse trabalho como Claire Beauchamp, Jamie Fraser, Black Jack, Geillis Duncan, Jenny Murray, entre outros. Nesse item, foi escrito uma síntese sobre esses personagens explicitando um pouco sobre quem eram, como eram, de onde eram, e qual relação cada um tinha com os outros personagens dentro da narrativa.

No capítulo 3 reside o objetivo principal deste trabalho de conclusão de curso. Nele, é utilizado todas as informações prévias, vindas tanto do capítulo 1 quanto do capítulo 2 já lidos e entendidos, principalmente, as informações dos personagens relevantes para o projeto e informações das teorias, conceitos, ondas e correntes feministas para basear as cenas da narrativa literária Outlander: a viajante do tempo em que as personagens femininas têm atitudes consideradas feministas.

Ao analisar as cenas escolhidas que seriam mais relevantes para este trabalho, optei por: cenas com ações de personagens femininas consideradas nos dias de hoje como atitudes feministas; e cenas com ações consideradas conservadoras e patriarcais como exemplo do patriarcado e machismo, sejam elas exercidas por homens ou por outras mulheres. Assim, entendi que o movimento feminista não pode parar e nem retroceder, pois, as mulheres necessitam desse apoio que a luta transmite.

Visto que na narrativa os exemplos de ações patriarcais ainda perpetuam até na atualidade, podemos, evidentemente, entender que o feminismo é extremamente importante e preciso para que as mulheres continuem a estudar, trabalhar, ter sua liberdade, sua opinião e voz. 
Então, com este trabalho de conclusão de curso, pude observar que a minha aceitação para com o movimento feminista cresceu e que estou mais consciente do meu dever como mulher em ajudar outras mulheres. Constatei também que estou contribuindo com a luta por meio desse trabalho e espero que ele possa alcançar muitas pessoas e que elas possam compreender o movimento e também apoiá-lo. 


\section{REFERÊNCIAS BIBLIOGRÁFICAS}

ARÁN, Márcia. O avesso do avesso: feminilidade e novas formas de subjetivação. Rio de Janeiro: Garamond, 2006.

ALVES, Branca Moreira; PITANGUY, Jaqueline. O que é feminismo? São Paulo: Abril Cultural: Brasiliense, 1991.

BEAUVOIR, Simone. O Segundo sexo. Tradução: Sérgio Milliet. 2. ed. Rio de Janeiro: Editora Nova Fronteira, 2009.

DAEMONOLOGIE. Amazon. Disponível em:

$<$ https://www.amazon.com.br/Daemonologie-original-illustrations-English-Scotlandebook/dp/B00GEG4BMW/ref=asc_df_B00GEG4BMW/?tag=googleshopp0020\&linkCode $=$ df0 \&hvadid $=412231984510$ \&vpos $=$ \&hvnet $w=g$ \& hrand $=1839409054$ 7971326781\&hvpone $=\&$ hvptwo $=\&$ hvqmt $=\&$ hvdev $=c \&$ hvdvcmdl=\&hvlocint $=\&$ hvlocphy $=1032056 \&$ hvtargid=pla-860706338310\&psc=1>. Acesso em: 5 out. 2020 .

DEBNATH, Neela. Outlander: Is Craigh na Dun a real place in Scotland? The real standing stones revealed. Express. Disponível em:

$<$ https://www.express.co.uk/showbiz/tv-radio/1238742/Outlander-Craigh-na-Dun-reallocation-where-Scotland-Inverness-stones-Clava-Cairns>. Acesso em: 5 out. 2020.

DIANA GABALDON. Twitter. Disponível em:

$<$ https://twitter.com/Writer_DG/status/1076515322562109440>. Acesso em: 5 out. 2020.

DIANA GABALDON ON 'OUTLANDER'. BBC. Disponível em: <https://www.bbc.com/news/av/uk-scotland-28834278>. Acesso em: 5 out. 2020.

DECRETO No 7.393, DE 15 DE DEZEMBRO DE 2010. Planalto Civil. Disponível em: <http://www.planalto.gov.br/ccivil_03/_ato2007-2010/2010/decreto/d7393.htm>. Acesso em: 5 out. 2020.

DRYSDALE, Neil. The Outlander Effect. The Press and Journal. Disponível em: <https://www.pressandjournal.co.uk/fp/news/scotland/2039021/the-big-interviewdiana-gabaldon-on-boiling-frogs-the-outlander-effect-and-being-pulled-over-by-thedundee-police/>. Acesso em: 5 out. 2020.

ECKMAN-ONYSKOW, Bev. Santa Fe author ready to release new book. Alamogordo News. Disponível em: <https://web.archive.org/web/20131112073342/http://www.alamogordonews.com/ne ws/ci_13204389>. Acesso em: 5 out. 2020. 
FAQ: ABOUT THE BOOKS. Diana Gabaldon. Disponível em:

$<$ http://www.dianagabaldon.com/resources/faq/faq-about-the-books/>. Acesso em: 5 out. 2020.

FAQ: ABOUT THE CHARACTERS. Diana Gabaldon. Disponível em:

$<$ http://www.dianagabaldon.com/resources/faq/faq-about-the-characters/>. Acesso em: 5 out. 2020.

FAQ: ABOUT DIANA. Diana Gabaldon. Disponível em: $<$ http://www.dianagabaldon.com/resources/faq/faq-about-diana/>. Acesso em: 5 out. 2020.

FOUCAULT, Michael. A História da Sexualidade I: a vontade de saber. Rio de Janeiro: Edições Graal, 1988.

Fox Play. Disponível em: <https://about.foxplay.com/apps/pt/index.php>. Acesso em: 5 out. 2020.

FROM SCIENCE TO FICTION. Northern Arizona University. Disponível em: <https://web.archive.org/web/20131111165845/http://nau.edu/News/Articles/2012/05/ From-science-to-fiction/>. Acesso em: 5 out. 2020.

GABALDON, Diana. Outlander: a viajante do tempo. Tradução: Geni Hirata. São Paulo: Editora Arqueiro, 2018.

GABALDON, Diana. The Outlandish Companion: Volume One. 2. ed. New York: Delacorte Press, 2015.

GONÇALVES, Marli. Feminismo no cotidiano: bom para mulheres. E para homens também... São Paulo: Contexto, 2019.

HAWKING, Stephen W. et al. O futuro do espaço-tempo. 8. ed. Tradução: José Viegas Filho. São Paulo: Companhia das Letras, 2005.

HOOKS, Bell. O feminismo é para todo mundo: políticas arrebatadoras. Rio de Janeiro: Rosa dos Tempos, 2018.

HUTCHEON, Linda. Poética do pós-Modernismo: história, teoria, ficção. Tradução: Ricardo Cruz. Rio de Janeiro: Imago Editora, 1991.

I GIVE YOU MY BODY. Diana Gabaldon. Disponível em: <http://www.dianagabaldon.com/books/i-give-you-my-body-how-i-write-sex-scenes/>. Acesso em: 5 out. 2020. 
Iqara Islam. Por que as Mulheres Muçulmanas usam Véu? Disponível em: <https://iqaraislam.com/por-que-as-mulheres-muculmanas-usam-veu>. Acesso em: 7 out. 2020.

JENAINATI, Cathia. Introducing: Feminism. Malta: Gutenberg Press, 2007.

KING, James the First of England. Daemonologie. Inglaterra: Aziloth Books, 2012. Disponível em: <https://www.amazon.com.br/Daemonologie-original-illustrationsEnglish-Scotlandebook/dp/B00GEG4BMW/ref=asc_df_B00GEG4BMW/?tag=googleshopp0020\&linkCode $=$ dfO\&hvadid $=412231984510 \&$ hvpos $=\&$ hvnetw $=g \&$ hvrand $=1839409054$ $7971326781 \&$ hvpone $=\&$ hvptwo $=\& h v q m t=\& h v d e v=c \& h v d v c m d l=\& h v l o c i n t=\& h v l o c p h y$ $=1032056 \&$ hvtargid=pla-860706338310\&psc=1>. Acesso em: 31 ago. 2020 .

LEI N 6.515, DE 26 DE DEZEMBRO DE 1977. Planalto Civil. Disponível em: <http://www.planalto.gov.br/ccivil_03/leis/l6515.htm>. Acesso em: 30 out. 2020.

LEI No 11.340, DE 7 DE AGOSTO DE 2006. Planalto Civil. Disponível em: <http://www.planalto.gov.br/ccivil_03/_ato2004-2006/2006/lei/l11340.htm>. Acesso em: 5 out. 2020.

LEI No 13.104, DE 9 DE MARÇO DE 2015. Planalto Civil. Disponível em: <http://www.planalto.gov.br/ccivil_03/_ato2015-

2018/2015/lei/l13104.htm\#: :text=LEI\%20N\%C2\%BA\%2013.104\%2C\%20DE\%209,n o\%20rol\%20dos\%20crimes\%20hediondos>. Acesso em: 5 out. 2020.

LIMA, Telma C. S. MIOTO, Regina Célia Tomaso. Procedimentos metodológicos na construção do conhecimento científico: a pesquisa bibliográfica. Revista Katálysis, v. 10, n.1, p. 37-45, 2007.

LORD JOHN GREY SERIES. Diana Gabaldon. Disponível em:

<http://www.dianagabaldon.com/books/lord-john-grey/>. Acesso em: 5 out. 2020.

MARANHÃO $\mathrm{F}^{\circ}$, Eduardo Meinberg de Albuquerque (org.). Anais do $1^{\circ}$ Simpósio Sudeste da ABHR / $1^{\circ}$ Simpósio Internacional da ABHR - Diversidades e (in)tolerâncias religiosas. São Paulo, 2013.

MCCANN, Hannah [et al.]. O livro do feminismo. Tradução: Ana Rodrigues. 1. ed. Rio de Janeiro: Globo Livros, 2019.

MCKENZIE, Steven. Outlander author Diana Gabaldon on her love of comics. BBC. Disponível em: <https://www.bbc.com/news/uk-scotland-highlands-islands-28840596 Acesso em: 5 out. 2020.

MELLO, Luiz. Novas famílias: Conjugalidade homossexual no Brasil contemporâneo. Rio de Janeiro: Garamound, 2009. 
Metacritic. Disponível em: <https://www.metacritic.com/>. Acesso em: 5 out. 2020.

MONTEIRO, Maria Conceição (Org.). Dialogando com Culturas: Questões de Memória e Identidade. Niterói: Vício de Leitura, 2003.

Musawah. Disponível em: <https://www.musawah.org/>. Acesso em: 7 out. 2020.

NEWSROOM, The. Interview: Diana Gabaldon. The Scotsman. Disponível em: $<$ https://www.scotsman.com/news/interview-diana-gabaldon-2442942>. Acesso em: 5 out. 2020.

O QUE É DELEGACIA ESPECIALIZADA NO ATENDIMENTO À MULHER (DEAM)? Governo Federal. Disponível em: <https://www.gov.br/mdh/pt-br/navegue-portemas/politicas-para-mulheres/arquivo/arquivos-diversos/acesso-ainformacao/perguntas-frequentes/violencia/o-que-e-delegacia-especializada-noatendimento-a-mulher-deam>. Acesso em: 5 out. 2020.

OUTLANDER AUTHOR DIANA GABALDON ANSWERS YOUR QUESTIONS. BBC. Disponível em: <https://www.bbc.com/news/av/uk-scotland-34909433>. Acesso em: 5 out. 2020.

OUTLANDER AUTHOR DIANA GABALDON INSPIRED BY MEN IN KILTS. BBC. Disponível em: <https://www.bbc.com/news/uk-scotland-37467296>. Acesso em: 5 out. 2020.

OUTLANDER THE MUSICAL. Amazon. Disponível em: <https://www.amazon.com/Outlander-Musical-Kevin-Walsh/dp/B00434DA56>. Acesso em: 5 out. 2020.

OUTLANDER. Audible. Disponível em:

<https://www.audible.com.au/series/Outlander-Audiobooks/B00FS3IDIK>. Acesso em: 5 out. 2020 .

OUTLANDER FILMING LOCATIONS. Visit Scotland. Disponível em: <https://www.visitscotland.com/see-do/attractions/tv-film/outlander/>. Acesso em: 5 out. 2020.

OUTLANDER THE MUSICAL. Diana Gabaldon. Disponível em: <https://www.dianagabaldon.com/misc/outlander-the-musical/>. Acesso em: 5 out. 2020.

PORTO, Dr. Maria Laura. Anencefalia e Poder Judiciário. Federação Brasileira das Associações de Ginecologia e Obstetrícia. Disponível em: <https://www.febrasgo.org.br/pt/noticias/item/138-anencefalia-e-poder-judiciario>. Acesso em: 5 out. 2020. 
PRIESTLEY, J. B.; SPEAR, Josephine. Adventures in English Literature. Vol. 1. USA: Harcourt Brace Jovanovich, 1963.

REIS, T. (Org.). Manual de Comunicação LGBTI+. 2. edição. Curitiba: Aliança Nacional LGBTI / GayLatino, 2018. Disponível em:

<https://www.grupodignidade.org.br/wp-content/uploads/2018/05/manualcomunicacao-LGBTI.pdf>. Acesso em: 5 out. 2020.

Robert Louis Stevenson Website. Disponível em: <http://robert-louisstevenson.org/>. Acesso em: 5 out. 2020.

Rotten Tomatoes. Disponível em: <https://www.rottentomatoes.com/>. Acesso em: 5 out. 2020.

SCARPIM, Fábio Augusto. DOIS EM UMA CARNE: IGREJA E

SEXUALIDADE NA HISTÓRIA. História: Questões \& Debates, Curitiba, volume 62, n.1, p. 265-277, jan./jun. 2015. Disponível em:

<https://revistas.ufpr.br/historia/article/view/38590/26702>. Acesso em: 21 out. 2020.

SERVIÇOS DISPONÍVEIS NA CASA DA MULHER. Governo Federal. Disponível em: <https://www.gov.br/mdh/pt-br/navegue-por-temas/politicas-paramulheres/arquivo/assuntos/violencia/programa-mulher-viver-sem-violencia/servicosdisponiveis-na-casa-da-mulher-brasileira>. Acesso em: 5 out. 2020.

SERVIÇOS ESPECIALIZADOS DE ATENDIMENTO À MULHER. Senado Federal. Disponível em: <https://www12.senado.leg.br/institucional/omv/acoes-contraviolencia/servicos-especializados-de-atendimento-a-mulher>. Acesso em: 5 out. 2020.

SHOWALTER, Elaine. Anarquia Sexual: sexo e cultura no fin de siècle. Tradução: Waldéa Barcellos. Rio de Janeiro: Rocco, 1993.

SOUZA, Manoel de. Loucuras dos seriados. São Paulo: Editora Panda, 2004.

SPIN-OFF. Priberam. Disponível em: <https://dicionario.priberam.org/spin-off>. Acesso em: 5 out. 2020.

SPIN-OFF. WordReference. Disponível em:

<https://www.wordreference.com/enpt/spinoff>. Acesso em: 5 out. 2020.

STARHAWK. A dança cósmica das feiticeiras: guia de rituais para celebrar a Deusa. 8. ed. Rio de Janeiro: Nova Era, 2010. 
THE EXILE. Amazon. Disponível em: <https://www.amazon.com.br/Exile-DianaGabaldon/dp/0345505387/ref=sr_1_3?ie=UTF8\&qid=1437866519\&sr=8-

3\&keywords=the+exile>. Acesso em: 5 out. 2020.

THE OFFICAL OUTLANDER COLORING BOOK. Amazon. Disponível em: $<$ https://www.amazon.com.br/Official-Outlander-Coloring-BookAdult/dp/0399177531/ref=asc_df_0399177531/?tag=googleshopp0020\& linkCode $=$ df0\& hvadid $=37 \overline{9} 708531647$ \&vpos $=$ \&hvnetw $=g \&$ hvrand $=6717752626$ $351599946 \&$ hvpone $=\&$ hvptwo $=\&$ hvqmt $=\&$ hvdev $=c \&$ hvdvcm dl $=\&$ hvlocint $=\&$ hvlocphy $=$ 1032056\&hvtargid=pla-444979073994\&psc=1>. Acesso em: 5 out. 2020.

TÍTULOS DE OUTLANDER. Editora Arqueiro. Disponível em: <http://www.editoraarqueiro.com.br/series/genero/outlander/>. Acesso em: 5 out. 2020.

VIANA, Jacqueline Plensack. Jane Austen, uma feminista disfarçada. Revista Polen. Disponível em: <https://revistapolen.com/jane-austen-uma-feministadisfarcada/>. Acesso em: 5 out. 2020.

VIANA, Rannyela. Estupro Marital frente aos deveres conjugais. Jusbrasil. Disponível em: <https://rannyelaviana.jusbrasil.com.br/artigos/416933770/estupromarital-frente-aos-deveres-conjugais?ref=feed>. Acesso em: 3 nov. 2020. 